OECDpublishing

SYNTHESISING GOOD PRACTICES IN FISCAL FEDERALISM

OECD ECONOMIC POLICY PAPER

April 2020 No. 28 
Economic Policy Paper No. 28

\title{
Synthesising Good Practices in Fiscal Federalism
}

Key recommendations from 15 years of country surveys

This paper has been prepared by:

\author{
Kass Forman \\ Sean Dougherty \\ Hansjörg Blöchliger
}

Authorised for publication by Luiz de Mello

Director, Policy Studies Branch, Economics Department 
The OECD Economic Policy Paper Series is published on the responsibility of the Secretary-General of the OECD. The opinions expressed and arguments employed herein do not necessarily reflect the official views of the Organisation or of the governments of its member countries.

Series: OECD Economic Policy Papers

SSN 2226583X

The statistical data for Israel are supplied by and under the responsibility of the relevant Israeli authorities. The use of such data by the OECD is without prejudice to the status of the Golan Heights, East Jerusalem and Israeli settlements in the West Bank under the terms of international law.

On 3 May 2018, the OECD Council invited Lithuania to become a Member. At the time of preparation, the deposit of Lithuania's instrument of accession to the OECD Convention was pending and therefore Lithuania does not appear in the list of OECD Members and is not included in the OECD zone aggregates.

On 25 May 2018, the OECD Council invited Colombia to become a Member. At the time of preparation, the deposit of Colombia's instrument of accession to the OECD Convention was pending and therefore Colombia does not appear in the list of OECD Members and is not included in the OECD zone aggregates.

This document and any map included herein are without prejudice to the status of or sovereignty over any territory, to the delimitation of international frontiers and boundaries and to the name of any territory, city or area.

(C) OECD 2020

You can copy, download or print OECD content for your own use, and you can include excerpts from OECD publications, databases and multimedia products in your own documents, presentations, blogs, websites and teaching materials, provided that suitable acknowledgment of OECD as source and copyright owner is given. All requests for public or commercial use and translation rights should be submitted to rights@oecd.org. Requests for permission to photocopy portions of this material for public or commercial use shall be addressed directly to the Copyright Clearance Center (CCC) at info@copyright.com or the Centre français d'exploitation du droit de copie (CFC) at contact@cfcopies.com. 
This OECD Economic Policy Paper combines insights from the cross-country research work of the Network on Fiscal Relations across Levels of Government and country experiences drawn from OECD Economic Surveys. It covers fiscal federalism chapters and policy recommendations from the Economic Surveys of Australia, Austria, Belgium, Brazil, Canada, the Czech Republic, Denmark, Finland, France, Germany, India, Indonesia, Italy, Japan, Korea, Mexico, The Netherlands, Norway, Spain, Sweden, Switzerland and the United States. Cross-country empirical research papers on fiscal federalism include:

Fiscal Federalism Studies and Working Papers on Fiscal Federalism, http://oe.cd/fiscalnetwork.

The work was carried out by Sean Dougherty and Kass Forman, based on earlier inputs from Hansjörg Blöchliger. This paper has benefited from comments and suggestions by delegates to the Network on Fiscal Relations. In particular, the authors would like to thank Luiz de Mello, Peter Hoeller, Dorothée Allain-Dupré, as well as the Belgian and Norwegian delegates to the Network. They also thank Celia Rutkoski for editorial assistance and Christopher Lomax for technical support. 


\section{Table of Contents}

Synthesising good practices in fiscal federalism .......................................................................... 7

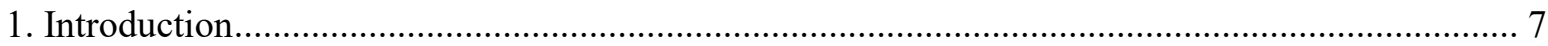

1.1. Policies for fiscal decentralisation: A meta-analysis of OECD country surveys ...................... 7

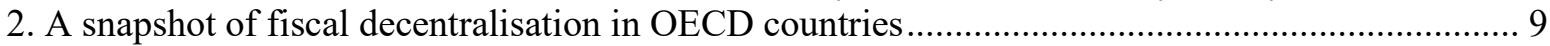

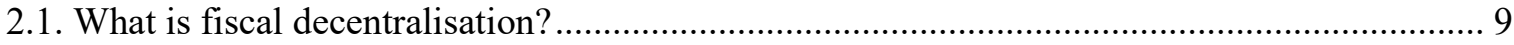

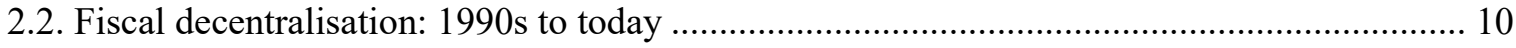

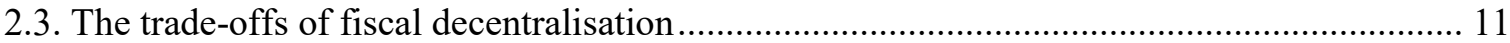

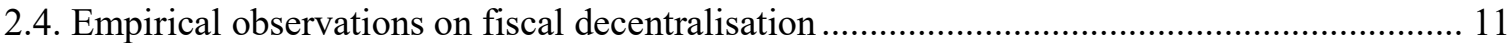

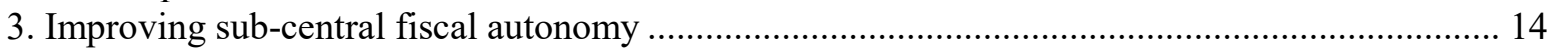

3.1. SCG fiscal autonomy: Adapting to local preferences while spurring competition,

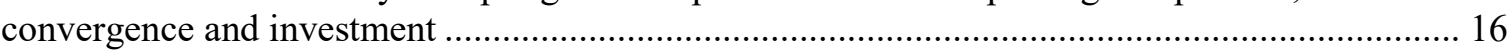

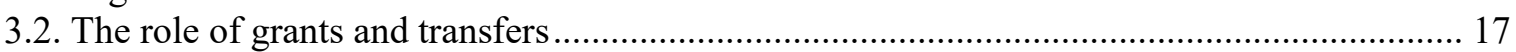

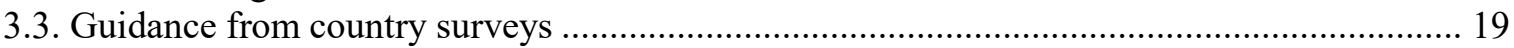

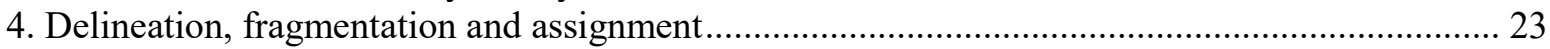

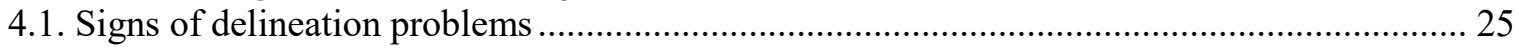

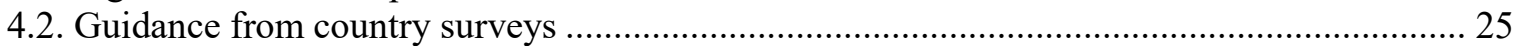

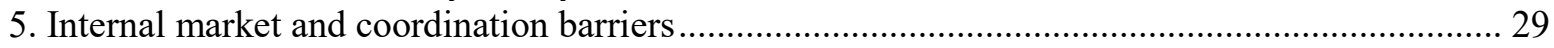

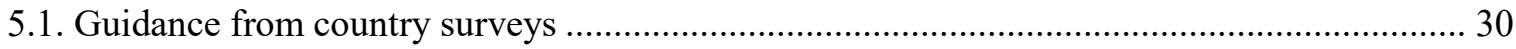

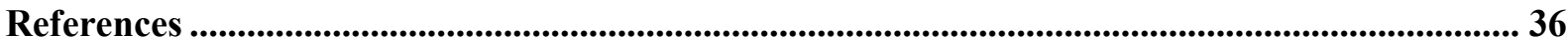

\section{Tables}

Table 1. Typical recommendations to improve fiscal capacity .......................................................... 19

Table 2. Surveys have called upon both federal and unitary countries to reduce vertical and

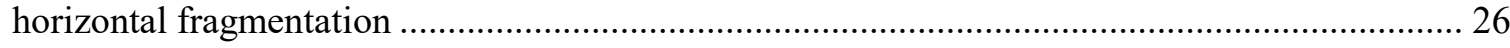

Table 3. There are seven major recommendations pertaining to reducing internal barriers and

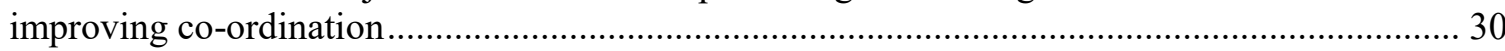

\section{Figures}

Figure 1. Linking diagnostic observations to recommendations ......................................................... 8

Figure 2. Revenue and spending assignment varies widely across countries....................................... 10

Figure 3. Decentralisation benefits middle-income earners ................................................................ 13

Figure 4. Decentralisation is positively associated with educational performance .............................. 14

Figure 5. The sub-central tax mix shifts from property to income taxes as decentralisation increases. 15

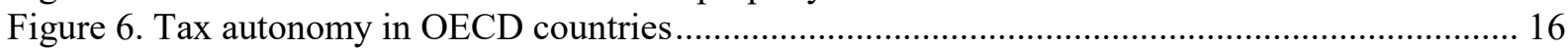

Figure 7. Unabsorbed EU structural and cohesion funds and spending of planned investment............ 31 


\section{Boxes}

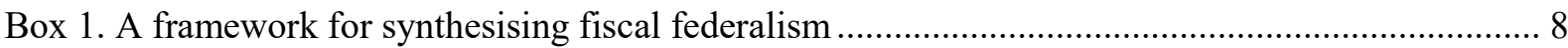

Box 2. SCG own-source revenues, tax autonomy and decentralisation ............................................. 15

Box 3. Quantitative evidence for fiscal autonomy's effect on regional convergence .......................... 17

Box 4. Ten guidelines for effective assignment of responsibilities to make decentralisation work...... 24

Box 5. Unabsorbed EU funds: an indicator of co-ordination failures and lack of capacity .................. 30 


\section{Abstract \\ Synthesising good practices in fiscal federalism: Key recommendations from 15 years of country surveys}

The design of intergovernmental fiscal relations can help to ensure that tax and spending powers are assigned in a way to promote sustainable and inclusive economic growth. Decentralisation can enable sub-central governments to provide better public services for households and firms, while it can also make inter-governmental frameworks more complex, harming equity. The challenges of fiscal federalism are multi-faceted and involve difficult trade-offs. This synthesis paper consolidates much of the OECD's work on fiscal federalism over the past 15 years, with a particular focus on OECD Economic Surveys. The paper identifies a range of good practices on the design of country policies and institutions related to strengthening fiscal capacity, delineating responsibilities across levels of government and improving intergovernmental co-ordination.

Keywords: Fiscal decentralisation, taxation, spending, public service delivery, intergovernmental co-ordination

JEL Classification: H71, H73, H75

\section{Résumé \\ Fédéralisme budgétaire - Établir une synthèse des bonnes pratiques : Principales recommandations issues de quinze années d'Études par pays}

La manière dont sont articulées les relations budgétaires entre les différentes composantes de l'administration peut contribuer à garantir que les compétences fiscales et les prérogatives en matière de dépenses sont réparties de façon à favoriser une croissance économique durable et inclusive. La décentralisation peut aider les administrations infranationales à offrir des services publics de meilleure qualité aux ménages et aux entreprises, mais peut aussi rendre plus complexes les cadres inter-administrations, avec des conséquences négatives en termes d'équité. Les enjeux du fédéralisme budgétaire sont multiples, et impliquent des arbitrages délicats. Le présent document de synthèse reprend une grande partie des travaux menés par l'OCDE sur le fédéralisme budgétaire au cours des quinze dernières années, en particulier dans les Études économiques de l'OCDE. On $\mathrm{y}$ recense un certain nombre de bonnes pratiques concernant la définition des politiques publiques et la conception des institutions d'un pays, considéré du point de vue du renforcement des capacités budgétaires, de la répartition des responsabilités entre les différents niveaux de l'administration et d'une meilleure coordination au sein de l'administration.

Mots-clés : Décentralisation budgétaire, fiscalité, dépenses, fourniture de services publics, coordination inter-administrations.

Classification JEL : H71, H73, H75 


\section{Synthesising good practices in fiscal federalism}

\section{Introduction}

1. Fiscal federalism refers to the distribution of taxation and spending powers across levels of government. Through decentralisation, governments can bring public services closer to households and firms, allowing better adaptation to local preferences. However, decentralisation can also make intergovernmental fiscal frameworks more complex and risk reinforcing interregional inequality unless properly designed. Accordingly, several important trade-offs emerge from the devolution of tax and spending powers. In addition, globalisation and the geographical concentration of economic activity are re-shaping fiscal frameworks with the role of the sub-national government level remaining vitally important (Boadway and Dougherty, 2019[1]).

2. This synthesis paper surveys both cross-country research on fiscal federalism and individual country experiences with the aim of consolidating OECD recommendations for improving fiscal relations across levels of government. To this end, it compiles the findings and recommendations presented in country-level Economic Surveys over the past fifteen years, since the inception of the Network on Fiscal Relations across Levels of Government. These recommendations do not presuppose the unique conditions that every jurisdiction faces nor suggest a single "recipe" for better outcomes. Rather, they give guidance to policymakers about what alternative policy options to consider, along with the associated trade-offs.

\subsection{Policies for fiscal decentralisation: A meta-analysis of OECD country surveys}

3. This paper analyses the OECD's rich database of country-level recommendations and empirical work to help identify the basis for effective fiscal relations across levels of government. It brings together three broad types of recommendations and associated sub-recommendations, which serve as general observations about good practices in fiscal federalism (Box 1). Figure 1 presents a selection of key diagnostic observations that tend to precede the three primary recommendations. 


\section{Box 1. A framework for synthesising fiscal federalism}

- Type I. "Fiscal capacity" recommendations: strengthen sub-national taxation and spending powers to allow governments to respond better to local needs and regional variations.

1. Better align own-source revenues with sub-central spending

2. Raise sub-central tax autonomy to ensure sufficient capacity

3. Strengthen fiscal equalisation systems

- Type II. "Delineation" recommendations: clearly delineate responsibilities both horizontally and vertically to improve efficiency and equity.

4. Delineate functions and responsibilities across levels of government clearly

- Type III. "Co-ordination" recommendations: minimize barriers to internal trade and enhance inter-governmental co-ordination.

5. Improve transparency, data collection and performance monitoring to enhance co-ordination

Figure 1. Linking diagnostic observations to recommendations

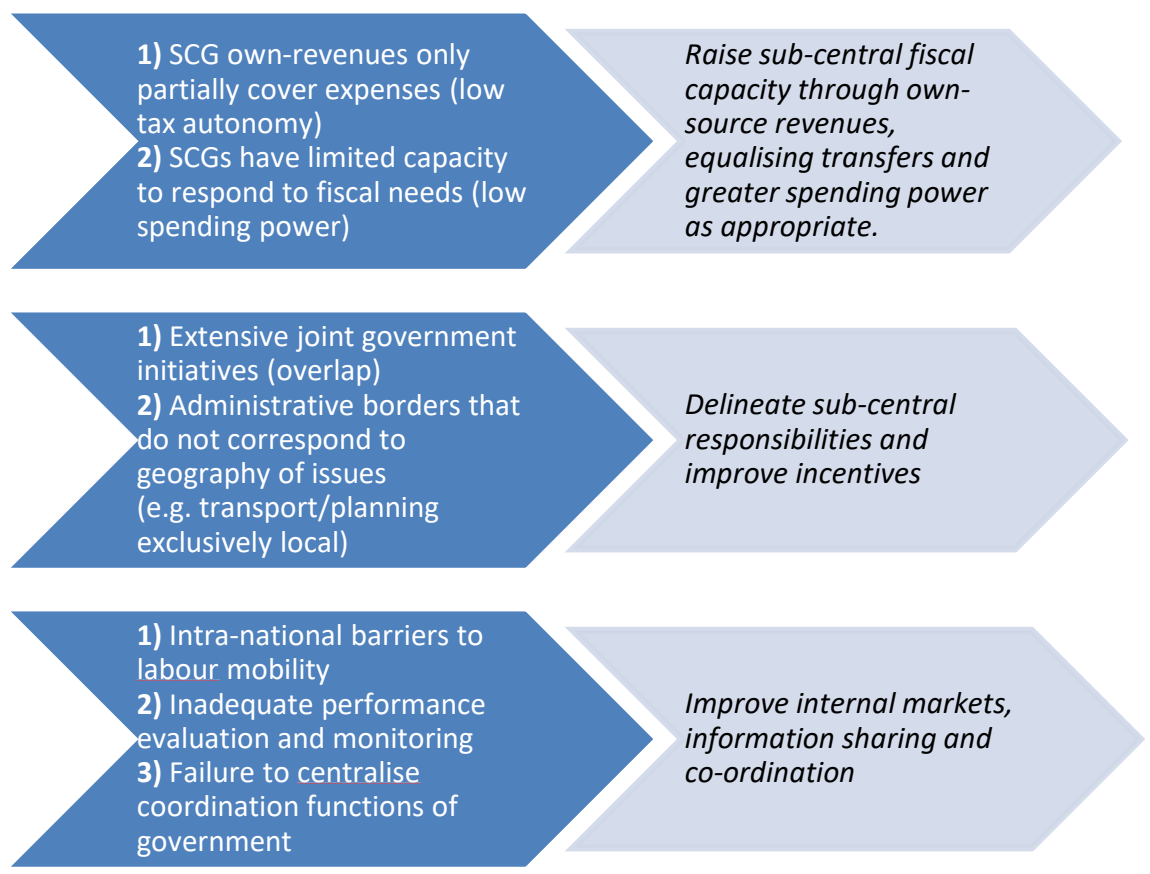




\section{A snapshot of fiscal decentralisation in OECD countries}

\subsection{What is fiscal decentralisation?}

4. Fiscal decentralisation refers to the assignment of tax and spending powers to subcentral governments (SCGs). The degree of fiscal decentralisation can be measured in terms of two components: tax autonomy and spending power. Tax autonomy describes the leeway that SCGs have over tax policy, such as the right to introduce or to abolish a tax, to set tax rates, to define the tax base, or to grant tax allowances/reliefs to households and firms. Spending power describes the level of control or authority of sub-national decision-makers over public spending, including deciding how services are organised, how funds are allocated, the preferred level and quality of inputs and outputs and how service delivery is measured and monitored. By bringing together tax autonomy and spending power, fiscal decentralisation captures the notion of aligning sub-central control over both taxation and budgets (OECD/KIPF, 2016 $[2])$.

5. Traditionally, tax autonomy and spending power have been quantified using SCG tax and spending shares, respectively, which are readily available on a consolidated basis in the OECD's Fiscal Decentralisation database annually. However, there are clear limitations to this approach. While SCG tax and spending shares give a rough indication of the extent of fiscal decentralisation, they fail to capture arrangements that lead SCGs to collect taxes or dispense funds without possessing control over e.g. the rate of the tax or the allocation of the funds. In response, the OECD's Network on Fiscal Relations has developed a set of tax autonomy and spending power indicators which seek to reflect more accurately the extent of sub-national control over taxation and spending.

6. The OECD tax autonomy indicator employs a system of eleven codes to classify tax instruments according to the degree of control possessed by sub-national government over the instrument in question. Codes range from a1, which indicates that the recipient SCG sets the tax rate and any tax reliefs without needing to consult a higher-level government, to e.g. d4, indicating a tax-sharing arrangement in which the revenue split is determined annually by a higher-level of government. In this way, the tax autonomy indicator captures the full spectrum of SCG control over taxation. From the inception of the Network on Fiscal Relations in 2002, the OECD has completed the tax autonomy study once every three years, with the latest analysis carried out in 2017, based on data for 2014, the most recent final data available at the time. This work has shown that SGCs in the OECD have significantly less tax autonomy than is suggested by simple share-based measures of decentralisation (OECD, $2013_{[3]}$ ).

7. Similar to the tax autonomy indicator, the OECD spending power indicator was developed to capture aspects of sub-national control over spending that are not revealed by the spending share alone. The spending power indicator employs survey data to score subnational autonomy in various sectors on a scale from 0 (less sub-national power) to 10 (more sub-national power). Within each sector, survey questions assess sub-national power along the several dimensions: policy autonomy (e.g., determination of policy objectives), budget autonomy (e.g., power to allocate funding), input autonomy (e.g., management of civil servants who design or provide public services), output autonomy (e.g., service standards), and evaluation/monitoring autonomy. The raw data are then used to compute scores for each sector, by country. The new indicators were published in Dougherty and Phillips (2020 $\left.{ }_{[4]}\right)$, which provides spending power scores for the education, long-term care, transport, housing and health care sectors. 


\subsection{Fiscal decentralisation: 1990s to today}

8. In the 1990s and the early 2000 s, many countries decentralised spending further, especially in education, infrastructure, environment and neighbourhood services. The resulting rise in the vertical fiscal imbalance - the difference between spending and own revenue - was met with the growth of grants or transfers. After the economic and financial crisis of 2008-09, the share of sub-central spending started to decline again. In contrast, the sub-central revenue share has changed little over the past two decades.

9. Today, intergovernmental fiscal frameworks vary widely across countries, but with some key similarities. For example, in all OECD countries spending is more decentralised than revenue (Figure 2, Panel a). Across the OECD, SCGs averaged one-third of total government spending and one-fifth of total revenue in 2015. In 2014, the SCG share of total revenue ranged from almost $50 \%$ in the case of Canada to less than $10 \%$ for Ireland and Greece. In terms of tax autonomy, State/regional governments on average have full discretion over $70 \%$ of their tax revenue (classified as a 1 by the tax autonomy indicator). Another $15 \%$ of their revenues come from shared taxes, where state governments' consent to the sharing ratio is required. In contrast, local governments, on average, have full or close to full autonomy over only $13 \%$ of their revenue. Nevertheless, local governments retain discretion, subject to some limitations, over an additional $62 \%$ of tax revenues on average (Dougherty, Harding and Reschovsky, 2019 $9_{[5]}$ ).

10. Meanwhile, spending power indicators for OECD countries suggest that subnational spending shares may exaggerate true SCG authority over spending. In many cases, substantial decision-making power over a given sector rests with a higher order of government even where some portion of the funding comes from the sub-national level. SCG spending power is higher in federal than unitary countries, and higher in the housing, transport and education sectors as compared to the health and long-term care sectors (Dougherty and Phillips, 2019 $\left[{ }_{[6]}\right)$.

Figure 2. Revenue and spending assignment varies widely across countries

a) Decentralisation ratios 2017

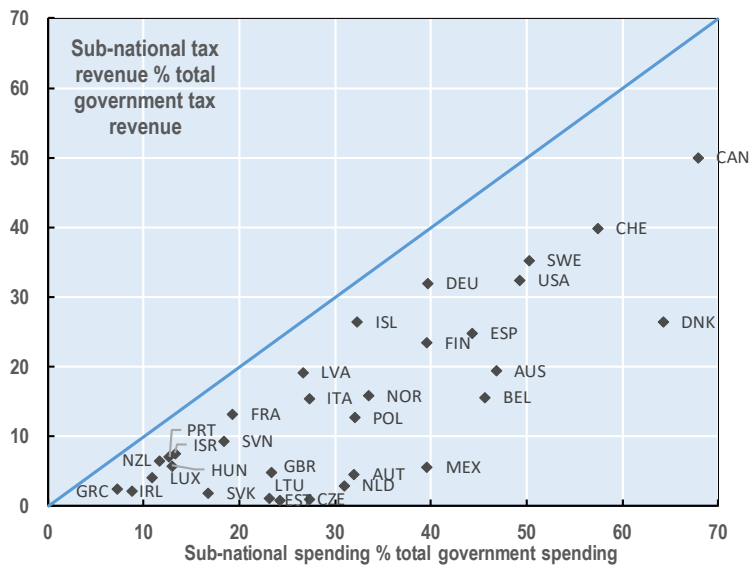

b) Decentralisation ratios, change $1995-2017$

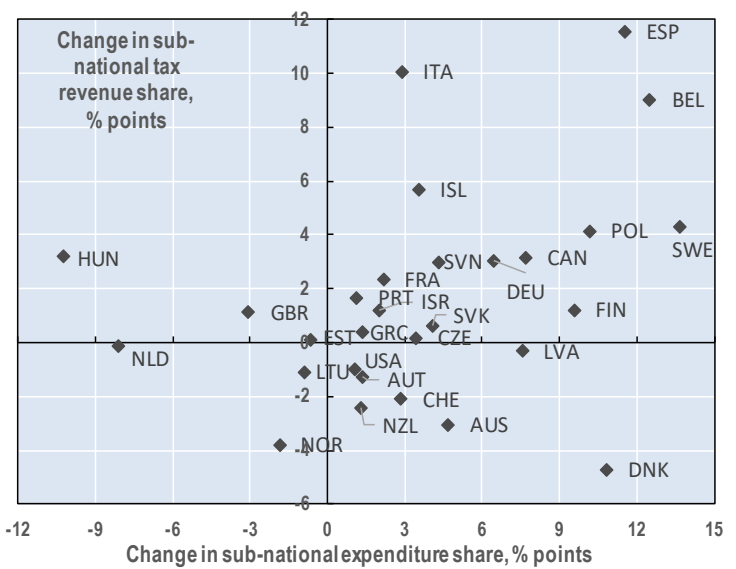

StatLink http://dx.doi.org/10.1787/888934116034

Note: The 45 degrees line in Panel A shows a situation where revenue decentralisation equals spending decentralisation. The farther away a country is from that line, the larger its vertical fiscal imbalance. In Panel B, Iceland's position represents the change between 1998 and 2017, the earliest year for which data are available. Source: OECD Fiscal Decentralisation database. 


\subsection{The trade-offs of fiscal decentralisation}

11. The modern theoretical underpinnings of decentralisation originated with Oates $\left(1972_{[7]}\right)$. The decentralisation theorem posits that, assuming no cost savings from centralisation, aggregate welfare across a set of jurisdictions will be superior when each jurisdiction is allowed to select its own public consumption bundle as opposed to when uniform consumption is provided across all jurisdictions. Obviously, this simple statement of the theorem does not account for the loss of economies of scale or a myriad of other factors that may intervene as fiscal decentralisation increases.

12. In practice, the policymaker faces a set of multi-dimensional trade-offs when designing intergovernmental frameworks for fiscal decentralisation. Previous work by the Network has discussed how decentralised fiscal frameworks allow for catering to local preferences and needs, while more centralised frameworks help reap the benefits of scale $\left(\mathrm{OECD}, 2013_{[3]}\right)$. Another key trade-off derives from the effect of decentralisation on the cost of information to different levels of government. While greater decentralisation implies that sub-national governments can access more information about the needs of a constituency at lower cost, it simultaneously increases the informational distance between central and sub-national government. In turn, this may make information more costly from the perspective of the central government, impeding its co-ordination and monitoring functions (de Mello, 2019 ${ }_{[8]}$; de Mello, 2000 [9]).

13. Decentralisation could also engender a costly misalignment of incentives. For example, a "common pool" problem may arise when decentralisation narrows the subnational revenue base and raises the vertical fiscal gap (de Mello, 2000 ${ }_{[9]}$ ). In this case, the necessary reliance on revenue sharing with central government to ensure SCG fiscal capacity may also distort the cost/benefit analysis of sub-national governments-particularly in situations where an SCG realises a payoff without bearing the entirety of the associated cost. Rigid arrangements that entrench fiscal dependence on the central government may drive SCGs to manipulate tax-sharing agreements in order to increase their share while undermining their motivation to cultivate the local tax base. Therefore, the possible efficiency and equity gains from decentralisation are closely linked to mitigating the pitfalls of poorly designed revenue sharing (Kim, 2018 $\left.{ }_{[10]}\right)$.

14. In light of these trade-offs, recent empirical work has begun examining the nonlinear effects of fiscal decentralisation. This includes evidence of an inflection point for decentralisation within the health sector (Dougherty et al., 2019 $9_{[11]}$ ) and data, which suggest that decentralisation may have diminishing marginal effects on economic outcomes, as discussed further below.

\subsection{Empirical observations on fiscal decentralisation}

\subsubsection{Decentralisation and growth}

15. An extensive literature reports mixed effects of decentralisation on growth. Martinez-Vazques et al. $\left(2017_{[12]}\right)$ provides a survey outlining much of the work to date and underscoring the ambiguous results. Within-country studies are especially inconclusive (OECD, 2019 $\left.{ }_{[13]}\right)$. For example, studies of decentralisation among US States have found both positive e.g. Akai and Sakata $\left(2002_{[14]}\right)$ and negative effects e.g. Xie et al. $\left(1999_{[15]}\right)$ on growth. Similarly, studies of decentralisation and growth in China have reported both positive e.g. Qiao et al. $\left(2008_{[16]}\right)$ and negative effects e.g. Zhang and Zou $\left(1998_{[17]}\right)$. 
16. This ambiguity can be contextualized by economic theory. Blöchliger and Akgun $\left(2018_{[18]}\right)$ outline several channels that link decentralisation to growth, both positively and negatively. First, following Tiebout $\left(1956_{[19]}\right)$, decentralisation may allow the mobile resident (or, more generally, mobile factor of production) to trigger inter-regional competition by "voting with her feet". This pressure stimulates public sector productivity and, by extension, economic growth. Second, decentralisation may limit the power of special interests while enabling innovation and thereby fostering productivity. At the same time, other aspects of economic theory suggest a negative relationship between decentralisation and growth. For example, decentralisation may undermine economies of scale. Likewise, decentralisation may lead SCGs to be affected by externalities created by the policy choices of adjacent jurisdictions. In these cases, there is a risk of undersupply of public goods or inadequate taxation.

17. OECD research has found a broadly positive relationship between revenue decentralisation and growth, with spending decentralisation demonstrating a weaker effect, e.g., Blöchliger, Égert and Fredriksen $\left(2013_{[20]}\right)$, Blöchliger and Akgun $\left(2018_{[18]}\right)$ find that "tax decentralisation is more conducive to growth than spending decentralisation", with a 10 percentage point increase in tax decentralisation associated with 0.1 percentage points more economic growth. This is consistent with other recent studies, including Gemmell et al. $\left(2013_{[21]}\right)$ and Filippetti and Sacchi $\left(2016_{[22]}\right)$.

18. Nevertheless, the role of country-specific circumstances is an important caveat to cross-national findings, as outcomes may feed back into the decentralisation process. An empirical study by the OECD that takes account of potential endogeneity issues, Dougherty and Akgun (2018 [23] $)$, found that the marginal effect of further decentralisation varies across countries to a large degree, reflecting the degree of de facto centralisation or decentralisation of existing revenue and spending responsibilities.

\subsubsection{Decentralisation and inequality}

19. OECD research on decentralisation and inequality suggests both that country specifications matter and that the effects may differ depending on the part of the income spectrum considered. For instance, Stossberg and Blöchliger $\left(2017_{[24]}\right)$ find that increasing decentralisation by 1 per cent reduces the gap between the second richest and the median household income decile by 0.8 per cent. As such, decentralisation appears to reduce the gap between high and middle-income households but may leave low incomes behind, especially where jurisdictions have large tax autonomy (Figure 3). More broadly, Dougherty and Akgun $\left(2018_{[23]}\right)$ observe that further decentralisation would increase the 90/10 income decile ratio on average, although the marginal effects vary considerably by country. 
Figure 3. Decentralisation benefits middle-income earners

Impact of spending decentralisation on household income, by household income decile

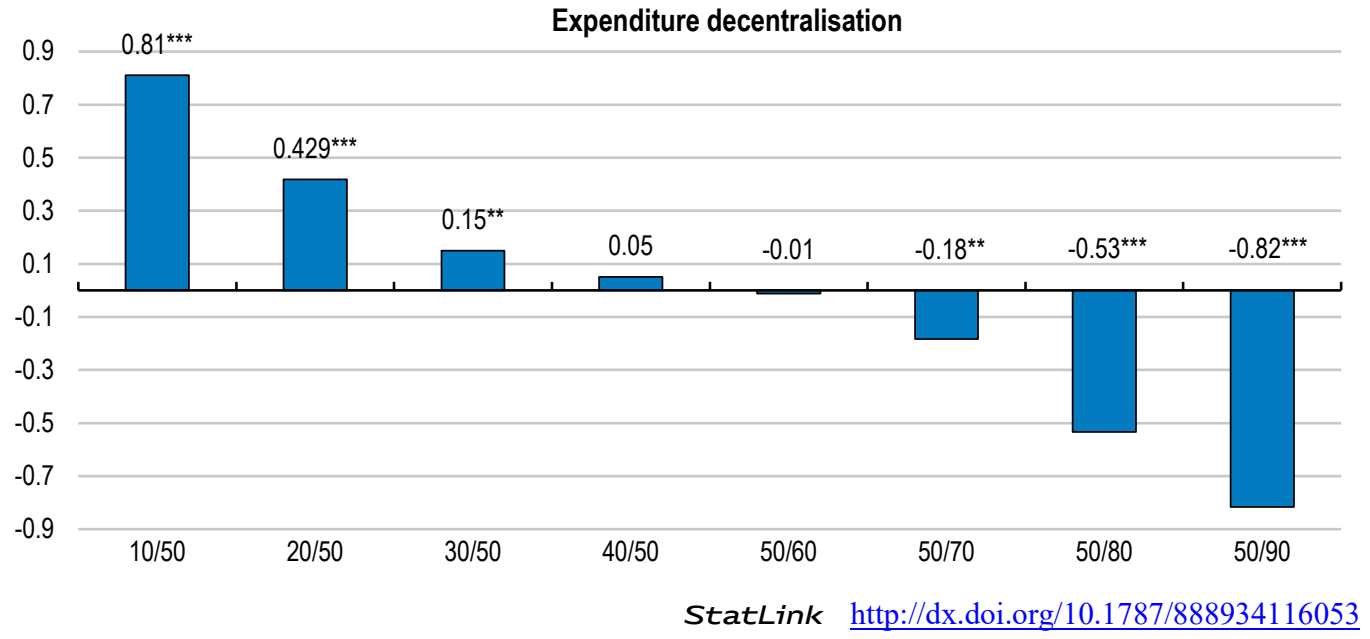

Note: Coefficients reflect percentage point changes, i.e. 0.43 means that a one percentage point increase in decentralisation (e.g. the spending share increases from $12 \%$ to $13 \%$ ) is associated with an increase by 0.43 per cent points of the ratio between the median and the respective household income decile. A negative coefficient means that increasing spending decentralisation reduces the gap between that income decile and the median income. A positive coefficient means the gap to the median income is widening. " $10 / 50$ " describes the poorest income decile, "50/90" the second-richest. Asterisks $(* * *, * *$ and $*)$ indicate the level of significance at the $1 \%, 5 \%$, and $10 \%$ levels, respectively.

Source: Stossberg and Blöchliger (2017 [24]).

\subsubsection{Decentralisation, public services and social capital}

20. Better adapting to the preferences of the community remains one of the key rationales for decentralisation. It is therefore unsurprising that decentralisation has been empirically connected to improved efficiency of public services, under the right institutional conditions (Sow and Razafimahefa, 2018 ${ }_{[25]}$ ). Moreover, by bolstering allocative efficiency, transparency, community participation and the perceived responsiveness of the public sector, fiscal decentralisation can engender greater social capital in the form of increased trust and cooperation (de Mello, 2004 [26]).

21. Consistent with the growth literature, recent work on sectoral decentralisation suggests both benefits and limitations to decentralisation as a policy to enhance the performance of the education and health care sectors. In healthcare, research suggests costs fall and life expectancy rises with moderate decentralisation, but the opposite effects hold once decentralisation becomes excessive (Dougherty et al., 2019 $9_{[11]}$ ). With respect to educational attainment, Lastra-Anadón and Mukherjee (2019 [27] $)$ find that a 10 percentage point increase in the sub-national revenue share improves PISA scores by 6 percentage points, corresponding to an average improvement by around six positions in the PISA country ranking. The positive correlation between sub-national tax revenue share and overall PISA scores in math, science and reading can be seen in Figure 4. A similar yet weaker relationship is found with other measures of education decentralisation, such as school autonomy or sub-national education spending. 
Figure 4. Decentralisation is positively associated with educational performance

Tax revenue decentralisation and overall PISA scores, 2015

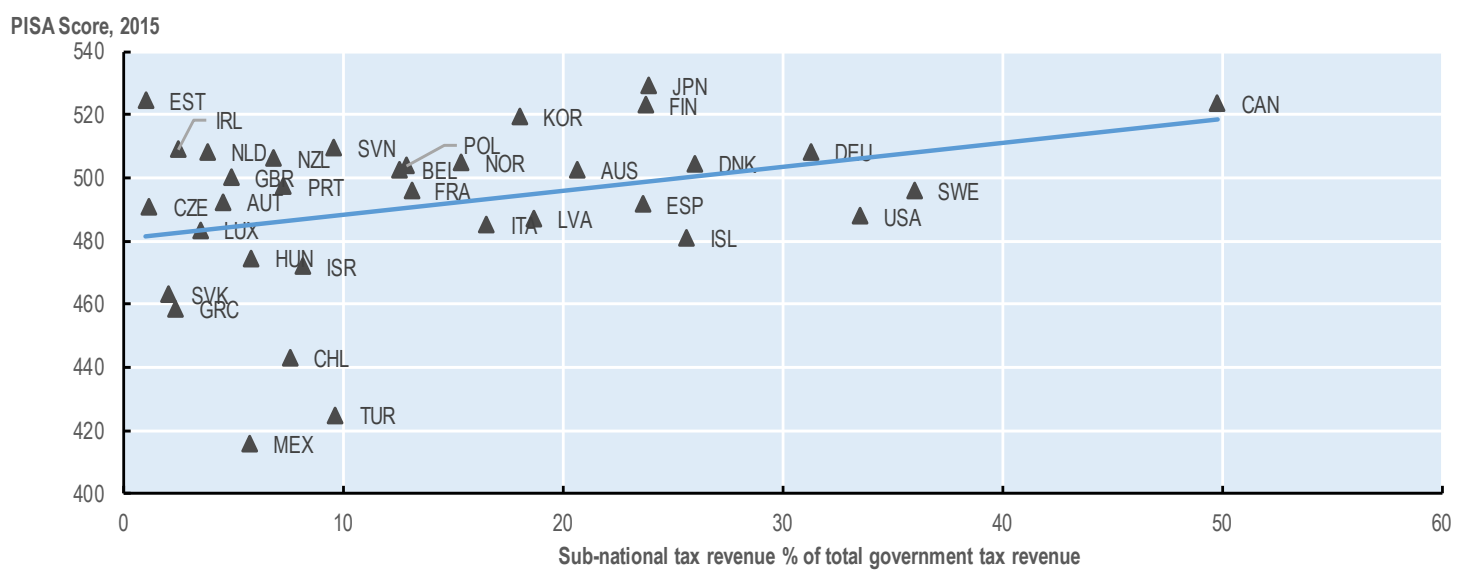

StatLink http://dx.doi.org/10.1787/888934116072

Source: Education at a Glance, OECD Fiscal Decentralisation database.

\section{Improving sub-central fiscal autonomy}

22. Of the roughly 163 country-level recommendations reviewed for this paper, around $28 \%$ called for a strengthening of sub-central fiscal autonomy. Fiscal autonomy itself is a rich concept, encompassing a diversity of measures that reinforce efficiency, equity and cohesion within and among SCGs. Important in enabling fiscal decentralisation, fiscal autonomy requires that SCGs receive adequate tax autonomy, spending power and/or fiscal equalisation (or similar transfers). In essence, fiscal autonomy should support the objective of ensuring that SCGs have sufficient fiscal capacity to fulfil their mandates. Depending on the structural context, fiscal autonomy may reduce the need for vertical transfers while allowing for better adaptation to local preferences. This implies that SCGs adjust their ownsource revenues to match their spending responsibilities. Where possible, the role of transfers should be to correct for structural income differences among SCGs and their respective tax revenue potentials, rather than to compensate for the failure to fully exploit the local tax base (Box 2). 


\section{Box 2. SCG own-source revenues, tax autonomy and decentralisation}

At present, SCGs draw their own-source revenues from a range of streams with income, property and consumption taxes being the primary instruments. Other taxes play a comparatively minor role. The tax mix itself appears strongly related to the extent of decentralisation, as shown in Figure 5. In more centralised countries, SCGs rely largely on (immovable) property taxes. Among the bottom 50\% of OECD countries in terms of SCG revenue as a percentage of total government revenue, property taxes constitute $48 \%$ of the SCG tax mix on average. As decentralisation increases, income taxes start to play a greater role. SCGs in the top quartile in terms of SCG revenue as a percentage of total government revenue see income taxes constituting on average $62 \%$ of their tax mix. The sub-national tax mix has changed relatively little over the last 20 years, with a decline in the share of property taxes and a rise in the share of consumption and income taxes especially personal income tax. Since around 2010, the property tax share has again been on the rise. Overall, the sub-national share of total taxation has hardly increased (see Figure 1, Panel b).

\section{Figure 5. The sub-central tax mix shifts from property to income taxes as decentralisation increases}

Sub-central revenues as a \% of total government revenue in OECD countries, with tax composition indicated, 2017-18

\% SCG tax revenue $\quad \square$ Income taxes $\quad \square$ Property taxes $\quad \square$ Goods and services taxes $\quad \square$ Other taxes $\quad \square$ Social security $\quad \square$ Payroll taxes

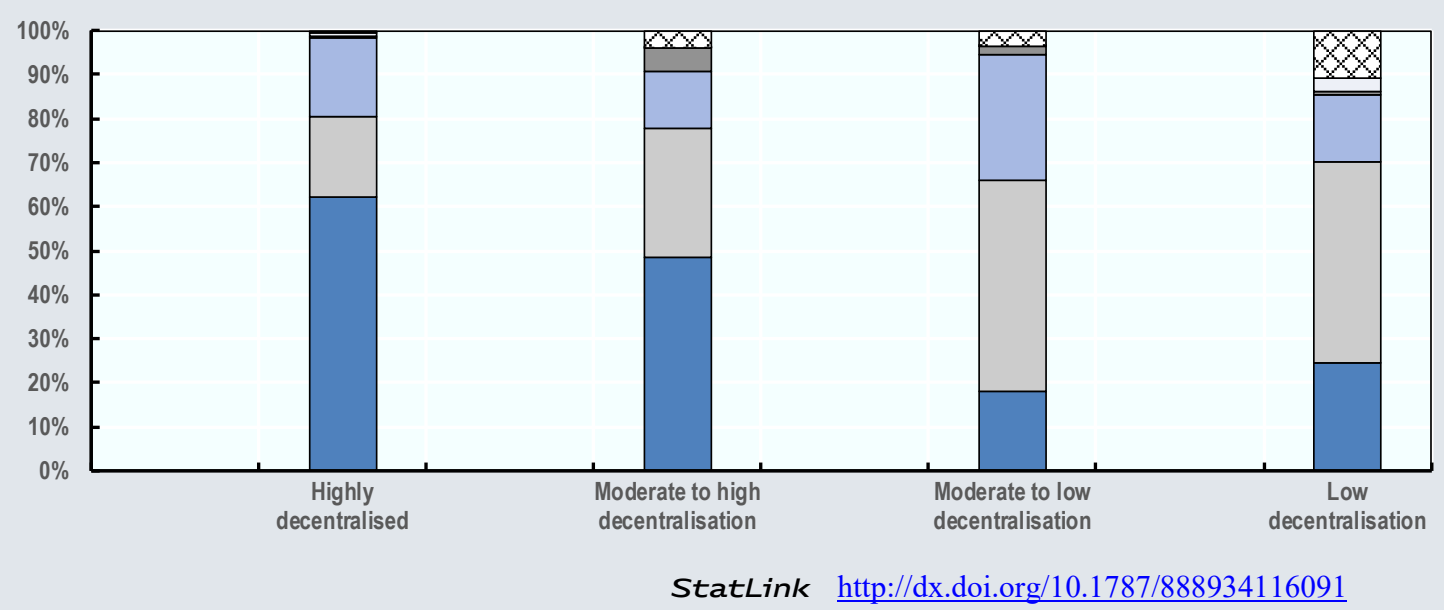

Note: Each column represents a quartile of OECD countries in order of decreasing sub-central revenues as a share of total government revenue. Revenues from tax-sharing agreements where the SCG does not control the rate are not included. Where data for 2018 was not available at the time of publication, data for 2017 was substituted.

Source: OECD Global Revenue Statistics database.

Like the SCG tax mix, sub-central tax autonomy varies substantially by country. In particular, a clear difference is apparent between the level of SCG tax autonomy in federal and unitary countries (Figure 6). Of the ten OECD countries with a federal or quasifederal structure (i.e. with state or regional governments), seven have a very high degree of tax autonomy. In three - Australia, Switzerland, and the United States - state-level governments have full autonomy over $100 \%$ of their tax revenue. In another three federal/quasi-federal countries-Canada, Belgium and Spain- over $90 \%$ of state-level 
revenue is classified as fully autonomous, and in one additional federation, Mexico, the share is over $80 \%$. In contrast, full SCG tax autonomy is infrequently observed within unitary countries. However, Dougherty et al. $\left(2019_{[5]}\right)$ notes that within 16 of 35 OECD countries examined, local governments have a substantial amount of tax autonomy, with full or restricted discretion on tax rates for at least $85 \%$ of their tax revenue.

\section{Figure 6. Tax autonomy in OECD countries}

\section{Sub-national tax revenue as a \% of total government tax revenue with tax autonomy indicated, 2014}

Federal \& regional countries on the left; unitary countries on the right

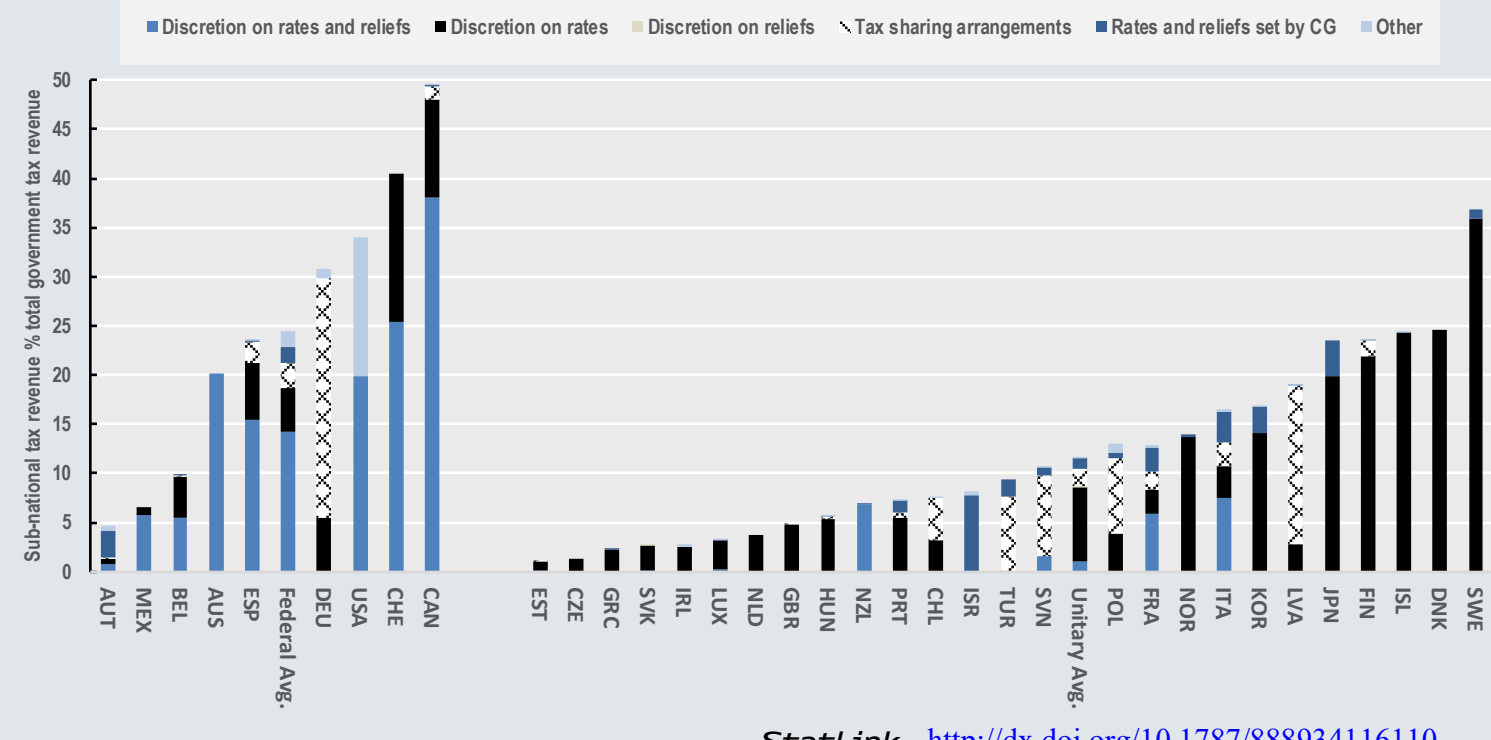

StatLink http://dx.doi.org/10.1787/888934116110

Note: For federal countries, the state- and local-level tax autonomy indicator values have been aggregated as a weighted average according to the respective tax revenue share of each level of sub-national government. The federal and unitary averages indicated above are computed based on the average tax shares and tax autonomy indicator values for the federal and unitary countries presented in the figure. The tax autonomy of local governments in the United States has been aggregated under the classification "other" to reflect the wide variety of taxing powers held by these governments.

Source: OECD Fiscal Decentralisation database.

\subsection{SCG fiscal autonomy: Adapting to local preferences while spurring competition, convergence and investment}

23. Consistent with the theoretical foundations established by Oates $\left(1972_{[7]}\right)$, enhancing SCG fiscal autonomy allows the bundle of public goods consumed to be selected locally, thus better matching local preferences. Additionally, sub-central fiscal autonomy enables interregional competition - not only in terms of tax rates, but just as importantly in terms of public services. Naturally, this may give rise to fears of predatory tax competition or worsening inequality. However, OECD research suggests that fiscal decentralisation is generally conducive to convergence, both in terms of tax rates and per capita income (Box 3).

24. Decentralisation has also been linked to greater public investment, with a $10 \%$ point increase in decentralisation (as measured by both SCG spending and revenue share of 
government total) "lifting the share of public investment in total government spending from around $3 \%$ to more than $4 \%$ on average" (Blöchliger, Égert and Fredriksen, 2013 [20] $)$. The investment driven by decentralisation appears to accrue principally to soft infrastructure, that is human capital as measured by education. As with tax rates and income, the link may be explained by the pressures of interregional competition, which drives productive investment as regions aim to attract workers and firms.

\section{Box 3. Quantitative evidence for fiscal autonomy's effect on regional convergence}

OECD research suggests that increasing SCG tax autonomy does not induce a "race to the bottom" with respect to sub-national tax rates. In fact, over the past couple of decades SCG tax rates have "trended up rather than down and generally converged over time" (OECD, $\left.2013_{[3]}\right)$. Moreover, fiscal autonomy may also be linked to regional income convergence. In a study of regions within OECD countries, Blöchliger et al. (2016 $\left.{ }_{[28]}\right)$ find that increasing sub-central own revenue share "by 10 percentage points is associated with a reduction of the regional GDP coefficient of variation between 3.6 and 4.3 percentage points" and that "increasing the [SCG] tax share by 10 percentage points reduces disparities by 2.4 to 2.8 percentage points" (Blöchliger, Bartolini and Stossberg, 2016 $\left.{ }_{[28]}\right)$. The study suggests that the underlying mechanism is related to the pressures of inter-jurisdictional competition. This may drive improved public sector performance, when SCGs have sufficient autonomy to respond to preferences.

\subsection{The role of grants and transfers}

25. Various circumstances may lead SCGs to be unable to fully fund their spending responsibilities using own-source revenues. The gap may be driven by a combination of both structural inequalities related to geography and income as well as inadequate fiscal autonomy. Filling the gap may require vertical transfers or grants from central government (and sometimes horizontal transfers from other SCGs). However, it is important to differentiate grants that rectify structural inequalities (e.g. equalisation) from grants that compensate for inadequate fiscal autonomy and displace own-source revenues. This is because excessive reliance on grants in place of own-source revenues can pose certain problems, particularly in the absence of a proper transfer design. In addition to their procyclical tendencies, grants are susceptible to the tumultuous character of political economy: complex formulas are vulnerable to rent seeking, which can cause an inefficient or regressive allocation of government spending. Lastly, grant-related dependence on other levels of government can reinforce deficit bias where the transfer system $\backslash$ rewards larger sub-central fiscal gaps (OECD, 2016[29]).

26. What then is the role of inter-governmental transfers? The report Fiscal Federalism 2014 (OECD, 2013 $\left.{ }_{[3]}\right)$ describes fiscal equalisation as the natural companion of fiscal autonomy, taking into account the fact that fundamental differences between regions will always lead to per capita revenue and cost discrepancies. With the aim of mitigating differences in service quality between regions, transfers in the form of equalisation payments should correct for economic conditions beyond the control of local government. Such transfers should ensure that SCGs have adequate fiscal capacity without discouraging optimal utilisation of the local tax base. Along these lines, the report provides some guidance with respect to the design of equalising transfers. First, revenue-equalising transfers should be calculated based on potential revenue (i.e. tax effort) as opposed to actual revenue. 
Second, cost-equalising transfers should be based on a few key indicators or standardised costs, not actual expenditure. Third, institutional measures such as arms-length oversight bodies and budget rules should be employed to help to ensure effectiveness.

27. A secondary role for inter-governmental transfers arises in ensuring budget predictability for local authorities. While local revenues may fluctuate, a stable system of transfers can aid with fiscal planning in the budget process. This is consistent with Making Decentralisation Work (OECD, 2019 $9_{[13]}$ ), which recognises the role of transfers in reinforcing inter-jurisdictional fiscal equity. For example, in Norway a robust system of inter-jurisdictional transfers seems to have supported comparatively lower disparities between urban and rural areas across a set of well-being indicators (e.g. income, internet access, air pollution, life expectancy, employment and post-secondary education) (OECD, $\left.2016_{[30]}\right)$. While fiscal autonomy can help to achieve greater efficiency and equity, it is important to avoid excessive revenue uncertainty at the local level, which could undermine service delivery.

28. Finally, it is important to consider country-level and regional contexts in determining the optimal mix of sub-central own-source revenues, grants and transfers. The Norwegian case highlights the role that regional preferences and the maintenance of rural economies can play when it comes to fiscal decentralisation. In other cases, economic surveys have noted that financial support from higher levels of government would be necessary to fund critical social infrastructure, such as for education in Germany (OECD, $\left.2018_{[31]} ; 2016_{[32]}\right)$. The broad cross-country variation that is visible with respect to the subcentral tax mix and tax autonomy underscores the fact that there is no one-size-fits-all approach to decentralisation, and that the monitoring of outcomes is essential (Box 2). 


\subsection{Guidance from country surveys}

Table 1. Typical recommendations to improve fiscal capacity

\begin{tabular}{|c|c|c|c|c|c|c|}
\hline \multicolumn{5}{|c|}{ Strengthen own-source revenues } & \multirow{3}{*}{$\begin{array}{c}\text { Raise SCG } \\
\text { spending } \\
\text { power }\end{array}$} & \multirow{3}{*}{$\begin{array}{l}\text { Reduce transfer } \\
\text { dependence } \\
\text { through } \\
\text { exploiting local } \\
\text { tax base }\end{array}$} \\
\hline \multicolumn{3}{|c|}{ Boost property taxation } & \multirow{2}{*}{$\begin{array}{l}\text { Piggy- } \\
\text { back } \\
\text { taxes }\end{array}$} & \multirow{2}{*}{$\begin{array}{c}\text { Improve } \\
\text { consumption } \\
\text { taxes/use } \\
\text { destination- } \\
\text { based VAT }\end{array}$} & & \\
\hline Raise rates & $\begin{array}{l}\text { Broaden } \\
\text { the base }\end{array}$ & $\begin{array}{l}\text { Update } \\
\text { valuations }\end{array}$ & & & & \\
\hline $\begin{array}{l}\text { Finland, } \\
\text { Denmark, } \\
\text { Mexico, the } \\
\text { Netherlands, } \\
\text { Korea }\end{array}$ & $\begin{array}{l}\text { Australia, } \\
\text { Mexico }\end{array}$ & $\begin{array}{l}\text { Austria, } \\
\text { Belgium, } \\
\text { Estonia, } \\
\text { Finland, } \\
\text { France, } \\
\text { Germany, } \\
\text { Greece, } \\
\text { Indonesia, } \\
\text { Mexico, } \\
\text { Portugal and } \\
\text { Sweden }\end{array}$ & $\begin{array}{l}\text { Austria, } \\
\text { Australia, } \\
\text { Korea }\end{array}$ & USA, Brazil & $\begin{array}{l}\text { Korea, } \\
\text { Belgium, } \\
\text { Australia, } \\
\text { Canada, Czech } \\
\text { Republic, } \\
\text { France, Japan, } \\
\text { USA }\end{array}$ & $\begin{array}{l}\text { Japan, German, } \\
\text { Belgium, Italy, } \\
\text { Switzerland }\end{array}$ \\
\hline
\end{tabular}

Note: This table depicts typical recommendations to improve SCG fiscal capacity followed by a sample of the countries to which they have been made. The first of the three primary recommendations in the top row strengthen own-source revenues - is divided into several sub-recommendations.

\subsubsection{Strengthening own-source revenues}

29. The principal survey recommendation related to fiscal autonomy is to strengthen the SCG tax base. Sometimes this is merely a matter of encouraging SCGs to employ powers that they currently possess, but have been hesitant to use for political reasons. For example, Spain was urged to encourage regional and local governments to more fully take advantage of their own taxing powers (OECD, 2007 $[33]$ ). Korea was advised to support SCGs in changing local income tax rates to increase self-sufficiency while avoiding volatile revenue sources like corporate taxes $\left(\mathrm{OECD}, 2008_{[34]}\right)$. In certain cases, SCGs do need new powers to secure own-source revenues. It was recommended that Mexico allow states to charge income and consumption taxes over and above the equivalent federal taxes (OECD, $2013_{[35]}$ ). Economic surveys have consistently recognised the importance of allowing SCGs to harness their own tax bases - not only to replace transfers, but also to motivate local authorities to pursue policies that encourage revenue-enhancing economic growth.

30. The following sections explore specific ways of strengthening own-source revenues, including property taxation, consumption taxes and income taxes. Hagemann $\left(2018_{[36]}\right)$ provides a detailed overview of sub-national taxation, but a few key observations deserve mention in this synthesis:

- Property taxation has distinct benefits, but these are undermined when valuations are out of date. For example:

1. Property taxes induce fewer behavioural distortions when compared with other taxes and are harder to avoid.

2. Property taxes tend to be progressive.

3. Empirical work suggests a shift to property taxation may be growth enhancing. 
- Consumption taxes have the advantage of efficiency (and when properly designed need not undermine equity). For decentralised countries, switching to a destinationbased VAT is often desirable, although this can limit the scope of SCG fiscal autonomy.

- Piggy-backing SCG income taxes on central government income taxes can help to allocate tax room between the two levels of government, but can also lead to administrative complexity (OECD, 2006 $[37]$ ).

31. Despite evidence that SCG tax autonomy does not induce a "race to the bottom" in terms of rates, the mobility of the tax bases assigned to the sub-central level retains a particular importance in the context of fiscal decentralisation. It is preferable that the less mobile tax bases are assigned to lower levels given the possibility of predatory tax competition between jurisdictions. Examples of taxes suitable for sub-national assignment include taxes on immobile bases, resource royalties, conservation charges, single stage sales taxes, motor vehicle registration taxes, business taxes, parking taxes, property taxes, and personal income surcharges. This contrasts with customs duties, value-added tax, corporate income tax, wealth/inheritance and carbon taxes which may be better levied at the national level (OECD, 2019[13]).

\subsubsection{Property taxes}

32. The recommendation to strengthen sub-national own revenue by increasing property taxation has featured across numerous country surveys. For 22 countries, surveys urged a "boost" to property taxation (Hagemann, 2018 [36]). Such a "boost" would typically take one of three forms: raising rates, broadening the base or updating valuations.

\section{Raising rates}

33. Raising rates, that is increasing the rate at which immoveable property is taxed, has been recommended in the case of Finland (OECD, 2014 [38]), Denmark (OECD, 2014 ${ }_{[39]}$; $\left.2012_{[40]}\right)$, Mexico (OECD, 2013 $\left.{ }_{[35]}\right)$, the Netherlands (OECD, 2010 $\left.0_{[41]}\right)$ and Korea (OECD, $\left.2005_{[42]}\right)$. In Finland, the survey noted that the central government had taken action to raise the band of permissible property tax rates from which municipalities could choose. Similarly, Mexico was advised to allow municipalities to decide their own property tax rates in an effort to increase them. The survey noted the particular challenge posed by the need for congressional approval to raise rates, creating a political incentive to deny permission. In the Korean case, the survey called for increasing local government revenues through greater taxation of property holdings. This would serve as a partial replacement for transaction taxes. Transaction taxes are seen to reduce labour mobility and land use efficiency, whereas taxes on property holdings may encourage efficient land use. In particular, the government was encouraged to accelerate the rise in effective tax rates on property holdings from 0.1 per cent to $1 \%$.

\section{Broadening the base}

34. SCGs should ensure that their property tax base is sufficiently broad by e.g. reducing exemptions and tax-free thresholds, as recommended in the cases of Australia (OECD, $\left.2006_{[37]}\right)$ and Mexico (OECD, 2013 $3_{[35]}$ ). The Australian survey noted that tax exemptions on the following types of holdings lead to an excessive narrowing of the property tax base: owner-occupied residential land, primary production land and land held by charities and religious bodies. Moreover, tax-free thresholds were set for low value commercial and 
industrial holdings. In fact, this created an incentive to sub-divide plots as a way of avoiding taxes. In Mexico, the property tax base was undermined by limited technical capacity to administer the tax system and failure to track property values and ownership.

Updating valuations

35. Out of date property values have been identified as lowering SCG property tax revenues across a range of surveys including Austria, Belgium, Estonia, Finland, France,

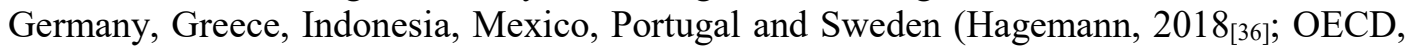
$2015_{[43]}$ ). In particular, the Austrian survey noted that "up-to-date valuation of real estate is a precondition for strengthening revenue-raising powers of municipalities on the basis of real estate taxes" (OECD, 2005[44]). In some cases, out of date values have been linked to infrequent updating of property registries (Almy, 2014 $\left.{ }_{[45]}\right)$. In Mexico, the lack of regular valuation kept taxed property values well below market value with data showing "cadastral values $60 \%$ below market values in about half of the 32 states" (OECD, 2013 [35]). In the Belgian case, a similar problem of infrequent valuations was observed. One solution discussed was devolving responsibility for updating the cadastre to the regions by creating regional cadastres. This would resolve the mismatch between the federal responsibility for updating valuations and the increases in regional revenues that would arise from the updates (OECD, 2015 $5_{[43]}$ ). Such a move would be broadly consistent with the objective of aligning revenues with responsibilities, as discussed in this Synthesis.

\subsubsection{Piggy-backing taxes}

36. A recurrent theme across both the Network's publications and the country surveys has been the balanced apportioning of fiscal room across central and sub-central government. In the interest of raising SCG fiscal autonomy, central governments may lower the taxes that currently flow to them and allow, encourage or require SCGs to increase their tax take. For example, in the case of "piggy-back" taxation, SCGs add their own income tax on top of the tax charged by central government. This can maintain administrative simplicity in cases where the piggy-backed tax is also collected centrally (and then distributed). It was suggested that Austria may consider doing precisely this, incorporating a state-level tax into its income tax schedule (OECD, 2005 $\left.{ }_{[44]}\right)$. To prevent shrinkage of the tax base, it was also suggested that the federal government should prescribe a range of rates from which all SCGs could choose. Piggy-backing income tax was also discussed in the case of Australia, where it was proposed that the states implement an income tax surcharge to replace grants that they had received from the commonwealth (OECD, 2006 [37] $)$. Ceding tax room to SCGs need not be restricted to income taxation. For example, it was recommended that Korea replace the nationwide comprehensive property tax (CPT) with increased local property taxes (OECD, $\left.2008_{[34]}\right)$.

\subsubsection{Improving consumption taxes: destination based VAT}

37. Consumption taxes are thought to be less distortionary and more conducive to growth than most other forms of taxation and policy options exist to enhance their progressivity (Cournède, Fournier and Hoeller, 2018 ${ }_{[46]}$ ). In the case of SCGs, some surveys have posited a destination based VAT as the preferred approach to the taxation of consumption. In contrast with origin-based taxes, destination-based taxes avoid distorting 
the producer's choice of location (given that the consumer is considered less mobile). ${ }^{1}$ Both the United States and Brazil were advised to consider this approach (OECD, 2005 $5_{[47]}$; $\left.2009_{[48]}\right)$.

\subsubsection{Raising SCG spending power}

38. The second component of fiscal autonomy is spending power. As spending power is typically more decentralised than tax autonomy (Figure 1, Panel a), it is unsurprising that measures to increase SCG spending power have been featured less prominently than measures to raise tax autonomy among the surveys reviewed. However, eight of the surveys did include explicit calls to increase the spending power of SCGs, typically through devolution of responsibility (an aspect of spending autonomy).

39. Adequate SCG spending power both enables adaptation to local preferences and reinforces a visible connection between local taxes and service provision, which drives efficiency and service improvements. This is particularly true in cases where the benefits of a certain service are localised to the jurisdiction where they are delivered (Oates and Schwab, $\left.1988_{[49]}\right)$. For example, in Korea the gap between the range of services available in communities - such as education and policing - and the limited role of local government in funding them, motivated recommendations to both raise local property taxes and assign greater spending responsibility to municipalities (OECD, 2008 ${ }_{[34]}$ ). Similarly, it was recommended that municipalities in Belgium take on financial responsibility for social assistance (OECD, 2009 $[50]$ ). Again, this was seen as a way of incentivising local government to provide more suitable and better-adapted support to the long-term unemployed. In bearing the cost of social assistance, municipalities would realise a monetary benefit from successfully transitioning people back into the labour market. In this way, reducing the cost of the service would require improving outcomes.

40. More broadly, recommendations that would increase the spending power of SCGs were also included in the Economic Surveys of Australia (give states full management of education funding), Canada (enhance municipal fiscal capacity), the Czech Republic (encourage municipalities to offer childcare), France (ensure regions have adequate fiscal capacity to support vocational training), Japan (provide local governments with greater financial resources), and the United States (assign responsibility for highway funding to states).

\subsubsection{Reducing transfer dependence}

41. While well-designed transfers can be an important source of SCG financing, under certain circumstances they can be replaced by stronger own-source revenues, which require less dependence on higher levels of government. The recommendation to reduce SCG dependence on transfers through raising own-source revenues has featured prominently in several country surveys. For example, it was observed that the former Japanese grant system undermined SCGs' incentives to develop own-source revenues (OECD, 2005 [51]). Subsequent economic surveys acknowledged the positive effect of the so-called "trinity reforms" in furthering fiscal decentralisation through the transfer of tax revenue from the centre to SCGs while simultaneously reducing grants. In fact, a recent survey provided evidence that these reforms have succeeded in reducing excessive allocation to public works

1. A destination-based tax implies that the final good is taxed where it is consumed, while an originbased tax implies that it is taxed where it originates. 
(in lieu of other priorities). Such excess had been associated with the perverse incentives of the former subsidy system (OECD, 2017 $\left.{ }_{[52]}\right)$.

42. In Germany, the issue of low fiscal autonomy of the Lander has been given extensive treatment in the Economic Surveys, leading to several recommendations aimed at reducing intergovernmental transfers. These included redesigning equalisation to enable the Lander to retain more own-source revenues, and increasing the scope of the Lander to generate such revenues (OECD, 2006 [53]). While the reform of Germany's transfer system remains challenging, the highly horizontal equalisation ${ }^{2}$ system is notable. OECD research suggests a number of advantages of horizontal equalisation systems, including more efficient redistribution and less pro-cyclicality (OECD, 2013 $\left.{ }_{[54]}\right)$. Improving SCG fiscal autonomy in the German context would involve counteracting the negative effects of SCG transfer dependence (failure to cultivate own-source revenues through taxation and economic development) while maintaining the advantages of the horizontal transfers.

\subsubsection{Transfer reform and own-source revenues: two sides of the same coin}

43. Belgium's country survey highlighted the complementarity of intergovernmental transfer reform and measures to strengthen own-source revenues (OECD, 2009 ${ }_{[50]}$ ). While the survey suggested reducing transfers to the regions (improving the revenue base of the federal government), SCGs were encouraged to utilise their own taxing powers to generate revenues. This advice was broadly reflected by the Sixth State Reform of 2012-14, which strengthened regional fiscal autonomy. Similarly, the economic surveys of Italy and Switzerland contained parallel recommendations to constrain transfers as a way of encouraging SCGs to cultivate their own tax bases (OECD, 2007 $\left.{ }_{[55]} ; 2015_{[56]}\right)$. In the Italian case, the use of a system of standardised costs and less than $100 \%$ equalisation was seen as the way to achieve this. In the Swiss case, there was a comparable recommendation to reduce transfers to cantons whose tax effort was below par.

\section{Delineation, fragmentation and assignment}

44. Delineation problems, that is to say fragmented and overlapping responsibilities, are a frequent concern in intergovernmental relations, especially in countries with several government layers. Naturally, it is always desirable to delineate responsibilities properly and to assign policy functions clearly. In achieving this goal, there are a few key signs of assignment problems and a few corresponding guidelines to be adhered to. These guidelines were developed in Allain-Dupré (2018[57]) and are summarised in Box 4.

\footnotetext{
${ }^{2}$ Horizontal equalisation refers to a system of fiscal equalisation in which SCGs with higher revenues make a contribution from their own-source revenues which is redistributed towards SCGs with lower revenues.
} 


\section{Box 4. Ten guidelines for effective assignment of responsibilities to make decentralisation} work

Ten guiding principles, which apply to all types of countries, have been identified. They are set out below:

1. Clarify the policy areas assigned to different government levels to avoid duplication, waste and loss of accountability.

2. Clarify the functions assigned to different government levels such as financing, regulating, strategic planning, implementing, or monitoring.

3. Ensure balance in the way different policy areas and functions are decentralised. This allows for complementarity and integrated policy packages for territorial development.

4. Align responsibilities and revenues while enhancing the capacity of sub-national governments to manage their own resources.

5. Actively support sub-national capacity building. More responsibilities at the subnational level need to be complemented with the human resources to manage them.

6. Build adequate co-ordination mechanisms across levels of government to manage shared responsibilities

7. Support cross-jurisdictional co-operation through specific organisational arrangements or financial incentives to increase efficiency through economies of scale.

8. Allow for asymmetric arrangements and pilot experiences to ensure flexibility in implementation.

9. Effective decentralisation requires complementary reforms in land-use governance, citizen participation and public service delivery.

10. Enhance data collection and strengthen performance monitoring to provide useful data for decision-making and peer learning.

Source: OECD (2019[13]).

45. Many of the assignment guidelines (Box 4) relate to the basic principle that subcentral spending should be covered by sub-central own taxes, with equalisation compensating for structural inequalities as opposed to a failure to exploit the local tax base. A similar idea is that the beneficiaries of and taxpayers for public services should be located in the same region. For example, if commuters from outside the city limits use the public transit system of the city in which they work, a regional public transit system should be created to cover the entire area. This minimises externalities and helps to define an optimal area size for an administrative region. 


\subsection{Signs of delineation problems}

46. Across a sample of 30 OECD countries, sub-central spending accounted for $48 \%$ of public expenditure on average for federal countries and $26 \%$ for unitary countries, ranging from more than 50\% in Canada, Denmark and Switzerland to less than 10\% in Ireland and Greece. However, this tells little about the actual spending power of the SCGs in question as spending power is typically more limited than spending shares would suggest. In reality, central governments may choose to delegate certain spending to sub-central governments while still exerting substantial control over service delivery (Dougherty and Phillips, $\left.2019_{[6]}\right)$.

47. The gap between observed sub-central spending shares and actual SCG spending power has been the subject of previous work by the Network (OECD/KIPF, 2016 [2]; Dougherty and Phillips, 2019 $\left.{ }_{[6]}\right)$. Examining the mismatch between spending shares and spending power scores can provide insight into the extent of delineation problems. For example, a high spending share accompanied by a low spending power score may indicate that the SCG functions merely as an agency charged with implementing the central government's policies. This may lead to excessive constraints on the SCG's ability to meet the needs of its constituents, undermining the core objective of decentralisation. Spending shares that belie spending power have been especially noted in the case of the Nordic countries. Denmark's "free municipality initiative" aims to overcome this by giving municipalities more leeway in structuring the services that they pay for (Allain-Dupré, $2018_{[57]}$ ). Meanwhile, spending power that outstrips spending shares could suggest a higher level of co-financing. Recent work on fiscal constitutions has discussed the risks associated with such misalignments, whereby SCGs may avoid ensuring adequate own-source revenue and instead rely on central government (e.g. implicit bailout guarantee) (OECD, 2016; Herold, 2018). OECD research has also identified strong, visible links between revenue and expenditure as important for tax morale (Daude, Gutiérrez and Melguizo, 2013 [58]). To the extent that multi-level financing arrangements obscure such links, they could be a cause for concern.

48. Even without data on the gap between spending share and spending power, qualitative evidence of fragmentation can suggest a delineation problem. One indicator of delineation problems is a lack of correspondence between administrative boundaries and the natural geographical expanse of a particular service, such as transportation or water governance. Reassigning public functions and undertaking coordinating between regions can lead to better alignment. For example, municipal mergers can go together with greater responsibilities for the merged administrations. In several countries, a new intermediate (regional) level was created to take over responsibility for higher education, specialised health care, transport infrastructure and economic affairs (OECD, 2019 $\left.9_{[13]}\right)$.

\subsection{Guidance from country surveys}

Fragmented and overlapping responsibilities represent a frequent challenge in intergovernmental relations, especially in countries with several government layers or many small SCGs. Fragmentation can occur across two dimensions: vertical and horizontal. In the former case, historical and other factors intervene to create situations where different parts of a policy or functions are parcelled out among different levels of government. In the latter case, numerous small SCGs are responsible for the same public services or administrative competencies within their own jurisdictions. Coordination failures and foregone economies 
of scale then arise from the fractured service provision and incongruous policies. Both horizontal and vertical fragmentation can seriously undermine the quality of public services, while leading to needless inefficiency. In response to vertical fragmentation, economic surveys have often recommended consolidating responsibility for an entire public service within a single level of government. In the case of horizontal fragmentation, they have tended to recommend enhanced cooperation or mergers between local governments.

Table 2. Surveys have called upon both federal and unitary countries to reduce vertical and horizontal fragmentation

References to fragmentation among country surveys reviewed

\begin{tabular}{|l|l|l|}
\hline Unitary countries & $\begin{array}{c}\text { Reduce vertical } \\
\text { fragmentation }\end{array}$ & $\begin{array}{l}\text { Reduce horizontal } \\
\text { fragmentation }\end{array}$ \\
\hline Spain, France & $\begin{array}{l}\text { Japan, Denmark, } \\
\text { Norway, France } \\
\text { Mexico, Belgium, } \\
\text { Austria }\end{array}$ \\
\hline & $\begin{array}{l}\text { Australia, } \\
\text { Switzerland, } \\
\text { Germany, Mexico }\end{array}$ & \\
\hline
\end{tabular}

\subsubsection{Complex systems like health care, education and social services are particularly susceptible to vertical fragmentation}

49. Among the surveys reviewed, nearly $40 \%$ of the delineation-related (Type II) recommendations pertained explicitly to health care, education or social services. This suggests that large, complex sectors face particular challenges with respect to overlap and fragmentation. For example, in terms of health care, the economic survey of Australia noted that primary care was allocated to the Commonwealth while States retained responsibility for public hospitals $\left(\right.$ OECD, 2014 $\left.4_{[59]}\right)$. This created opportunities for cost shifting, such as public hospitals passing the burden of post-operative care onto general practitioners. The same survey noted that Australia's education system was affected by "complex and opaque funding arrangements" involving multiple levels of government. In a similar vein, the French vocational training system was seen to suffer from delineation problems. A 2014 reform introduced roles for a diverse range of actors such as national government, regions, and chambers of commerce. In addition, co-ordinating bodies were put in place at both the national and regional levels. This lead to a lack of clarity with respect to overall responsibility for the new system (Brandt, 2015 $5_{[60]}$; OECD, 2015 [61]). In Mexico, the education system was found to be highly fragmented between the federal and state governments. An opaque, multi-part grant system was used to channel funds from the centre to the states, leading to asymmetries in the delivery of education services across the territory. In the area of social services, the economic survey of Spain identified a disconnect between the financing of unemployment benefits at the national level and the management and design of labour market reintegration support at the regional level (OECD, 2008 $\left.8_{[62]}\right)$. As regions received more funding when they faced a larger unemployed population, there was little incentive for them to design policies that reduce long-term unemployment.

\subsubsection{Assignment to a single level can be a remedy for fragmentation}

50. The typical remedy for fragmentation is to ensure that complete responsibility for a given public service is assigned to a single level of government. SCGs are often heavily involved in providing public services and assigning responsibility to them may allow for 
adaptation to local preferences. In the Australian case, the survey recommended clarifying roles and improving coordination between levels of government, while noting that in some cases reallocation of responsibility for an entire sector to a specific level of government may be necessary. This was consistent with the findings of Australia's National Committee of Audit (NCA), which argued for complete state-level control over funding allocations to schools. Similarly, the economic survey of France recommended that the respective roles of national and regional vocational training councils be clarified to ensure that they did not interfere with one another. In particular, it was recommended that spending responsibility be assigned to one actor (e.g. regions) (OECD, 2014 [63] ). In the case of the Spanish unemployment system, the survey suggested it would be ideal to assign both financial responsibility for unemployment benefits and implementation of active labour market policy (ALMP) to the same level of government. However, acknowledging the political complexity of the task, the survey called for better monitoring and evaluation of ALMP implementation.

\subsubsection{Co-funding in federations: an indication of fragmented assignment}

51. Multi-level co-funding, that is joint funding provided by multiple levels of government, be a sign of allocative inefficiency, particularly where interregional spillovers are unclear. Such inefficiency stems from fragmentation of funding responsibility across levels of government. In laying out a sustainable path towards fiscal consolidation, the economic surveys of both Germany and Switzerland (OECD, 2006 $\left.[53] ; 2006_{[64]}\right)$ highlighted inefficiencies arising from federal state co-funding arrangements. These include:

- States face an incentive to spend even when benefits are small as only a portion of the cost is born at the local level;

- Co-funding can undermine a clear connection between cost and service provision in the eyes of the public;

- Complex mediation processes between governments can slow things down;

- Co-funding requires costly administration and impedes program evaluation;

- The rigidity of earmarked funding from the federal government can undermine optimal allocation.

52. To resolve these challenges, the surveys recommend moving away from systems of earmarked co-funding based on expenditure. Instead spending responsibility should be clearly assigned to the SCGs, with fiscal inequality corrected by revenue equalisation. Consistent with these recommendations, the Swiss reform of 2003 reduced the grant system by around $30 \%$ by assigning funding and regulatory power either fully to the federal or state level. At the same time, the portion of total transfers to cantons available to help them shoulder their new responsibilities increased from 25 to $40 \%$ (OECD, 2006[64]).

53. It is important to note that where SCGs are unable to finance expenditure on critical social infrastructure such as primary education, well designed co-funding can play an important role. For example, the economic surveys recognized Germany's removal of constitutional barriers to federal co-funding of education as a positive step towards helping financially weak municipalities make important investments in local education infrastructure (OECD, 2018 [31]; OECD, 2016[32] $)$. 


\subsubsection{Horizontal fragmentation and geographical divisions}

54. Whereas the gap between spending share and spending power may suggest vertical fragmentation problems between levels of government, excessive geographic division of local services indicates horizontal fragmentation. Horizontal fragmentation may lead to an obvious inefficiency arising from the inability to exploit scale economies, however an additional inefficiency arises from the coordination problems associated with unnatural divisions of cross-jurisdictional issues. In these cases, cross-border externalities may lead to a mismatch between paying and benefitting jurisdiction. Synergies from amalgamating services across borders may improve outcomes, including in the areas of transport, urban waste management, water supply, fire-fighting and hospital administration (de Mello, $\left.2019_{[8]}\right)$.

55. Horizontal fragmentation is often related to geographically fragmented local governance. In these cases, responsibility for services is assigned to many smaller, local authorities even when the policy areas concerned cross boundaries. The Valle de México metropolitan area provides an example of failure to integrate policy across a region. Land use planning is largely divided along the boundary lines of the 51 municipalities in the area. Similarly, public transport provision is fragmented between Mexico City and the State of Mexico. One remedy would be to create metropolitan structures for cross-boundary public service delivery and integrated urban planning. A legal mechanism that fosters co-operation across different policy areas would overcome fragmentation (OECD, 2019 [65] $)$.

56. Where small municipalities are struggling to provide cost-effective public services, amalgamation of jurisdictions is an obvious solution but not always optimal. Inter-municipal cooperation arrangements are more flexible and can be designed to take into account the differing functional areas (geographical zones) that make most sense for a given service. Though sometimes outright mergers of small municipalities have been recommended, such as in France $\left(\mathrm{OECD}, 2015_{[61]}\right)$, Norway $\left(\mathrm{OECD}, 2010_{[66]}\right)$ and Austria $\left(\mathrm{OECD}, 2005_{[44]}\right)$, in Japan it was recommended that greater focus be placed on inter-municipal co-operation arrangements built around collaborations to provide an individual service or set of services. Underscoring the broad applicability of inter-municipal cooperation to avoid horizontal fragmentation, de Mello (2019 $\left.{ }_{[8]}\right)$ provides further examples of this approach in Finland, France, Italy and Turkey.

57. A particularly interesting response to geographical fragmentation is found in the Belgian case. Coordination problems related to water policy were observed to derive from the fact that authority in this area was assigned to regions, whereas river basins do not follow regional borders. It was therefore suggested that water policies be better integrated by establishing water authorities at either the river basin or the national level (OECD, 2011 ${ }_{[67]}$ ). Subsequent to this recommendation, Belgium's Sixth State Reform led to broad changes in the institutional context as more competences were devolved to the regions. Nonetheless, overcoming geographical fragmentation remains important. This is facilitated by crossregional bodies, such as the Groupe Directeur Eau which co-ordinates interested parties in the area of water governance (Bruxelles environnement, 2019 ${ }_{[68]}$ ).

58. In certain cases, geographical fragmentation has motivated the creation of new regional levels of government. In Denmark, a wide-ranging municipal government reform was partially motivated by the view that health care provision was too fragmented across small administrative units. In response, health care responsibilities were re-assigned to one of five newly created regions (OECD, 2012[699]). 


\section{Internal market and coordination barriers}

59. Intergovernmental fiscal relations are by no means restricted to questions of fiscal policy. Co-ordination and information flows also play a central role in effective fiscal federalism. For example, co-ordination failures may lead to different levels of government working at cross-purposes. Lack of monitoring and benchmarking may allow service standards to slip, particularly when data are absent or inaccessible. Regulatory barriers to intra-national trade may hamper the free flow of goods, capital and labour within a country. Needless variation in SCG procedures may undercut the benefits of scale, particularly in the area of procurement. Finally, inadequate human and physical capital within the sub-national public service can impede policy implementation.

60. Avoiding these issues in decentralised settings requires adequate inter-governmental fiscal co-operation (IFC). For example, IFC can reinforce regulatory coherence between levels of government, while reducing policy contradictions or tensions and eliminating internal market barriers. Similarly, co-operation can facilitate the sharing of skills and technologies between SCGs. It can also create "peer pressure" to support adhering to agreedupon rules or adopting common standards. Finally, IFC can help SCGs harness economies of scale in both important areas of public spending (e.g. infrastructure) and administration (e.g. taxation or procurement) (Ter-Minassian and de Mello, 2016 $6_{[70]}$; de Mello, 2019 ${ }_{[8]}$ ).

61. Quintessential examples of IFC in practise are provided by both Canada (federal) and Denmark (unitary). In Canada, the Council of the Federation, a body composed of provincial and territorial Premiers, acts as a forum for IFC. It has promoted co-operation in the areas of internal trade, health care, water resources, energy and transportation (TerMinassian and de Mello, 2016[70] $)$. In Denmark, a 2007 reform of local government was characterised by complementary vertical fiscal co-operation (additional grants and funds from central government to compensate SCGs for new costs) and horizontal fiscal cooperation (mergers of municipalities). This increased the acceptability of the reform while reducing the incentive to cost-shift between levels of government. In this case, IFC served to link "a territorial reform, a reallocation of tasks across levels of government, and a financing and equalisation system reform. This allowed compensating costs and benefits to carry over from one reform element to the other" (OECD, 2012 [69]).

62. Based on a synthesis of OECD economic surveys, seven broad types of recommendations to support IFC in decentralised settings were identified: improve policy alignment and co-ordination between levels of government, eliminate internal market barriers and reduce regulatory fragmentation, enhance monitoring including through oversight at the national level, benchmark performance nationally and internationally, improve the quality and accessibility of performance measurement data, implement joint procedures and centralise procurement across SCGs, and build SCG professional capacity. Table 3 shows, which countries have been subject to these recommendations. 
Table 3. There are seven major recommendations pertaining to reducing internal barriers and improving co-ordination

References to reducing internal barriers and improving coordination among country surveys reviewed.

\begin{tabular}{|c|c|c|c|c|c|c|c|}
\hline & $\begin{array}{l}\text { Improve policy } \\
\text { alignment and } \\
\text { co-ordination } \\
\text { between levels } \\
\text { of government }\end{array}$ & $\begin{array}{l}\text { Eliminate } \\
\text { internal } \\
\text { market } \\
\text { barriers and } \\
\text { regulatory } \\
\text { fragmentation }\end{array}$ & $\begin{array}{l}\text { Enhance } \\
\text { monitoring, } \\
\text { including } \\
\text { through } \\
\text { oversight at } \\
\text { the national } \\
\text { level }\end{array}$ & $\begin{array}{l}\text { Benchmark } \\
\text { performance } \\
\text { nationally and } \\
\text { internationally }\end{array}$ & $\begin{array}{l}\text { Improve } \\
\text { quality and } \\
\text { accessibility } \\
\text { of } \\
\text { performance } \\
\text { measurement } \\
\text { data }\end{array}$ & $\begin{array}{l}\text { Implement } \\
\text { joint } \\
\text { procedures } \\
\text { and/or } \\
\text { centralise } \\
\text { procurement } \\
\text { across SCGs }\end{array}$ & $\begin{array}{l}\text { Build SCG } \\
\text { professional } \\
\text { capacity }\end{array}$ \\
\hline Australia & $\checkmark$ & & & & $\checkmark$ & & \\
\hline Austria & $\checkmark$ & & & $\checkmark$ & & & \\
\hline Belgium & $\checkmark$ & $\checkmark$ & $\checkmark$ & & & & \\
\hline Canada & & $\checkmark$ & & & & & \\
\hline Czech Republic & $\checkmark$ & & & & & & \\
\hline Denmark & & & $\checkmark$ & & & & \\
\hline France & & & & & $\checkmark$ & $\checkmark$ & $\checkmark$ \\
\hline Germany & & $\checkmark$ & & & $\checkmark$ & & $\checkmark$ \\
\hline India & & & & $\checkmark$ & & & \\
\hline Indonesia & & & & & & & $\checkmark$ \\
\hline Italy & $\checkmark$ & & & $\checkmark$ & $\checkmark$ & $\checkmark$ & \\
\hline Mexico & & & $\checkmark$ & & $\checkmark$ & & $\checkmark$ \\
\hline Spain & $\checkmark$ & $\checkmark$ & $\checkmark$ & $\checkmark$ & & & \\
\hline Switzerland & $\checkmark$ & $\checkmark$ & $\checkmark$ & & $\checkmark$ & $\checkmark$ & \\
\hline
\end{tabular}

\subsection{Guidance from country surveys}

\subsubsection{Improve policy alignment and co-ordination across levels of government}

63. Any form of multi-level governance introduces the possibility that different levels of government may be working at cross-purposes. In the context of fiscal decentralisation, the prospect of contradictory, poorly co-ordinated or misaligned policy takes on new dimensions as questions of efficiency and incentives come into play. Indeed, co-ordination across levels of government, and in particular vertical co-ordination, has been identified as a key challenge in governance and fiscal policy by the OECD, IMF and European Committee of the Regions (Allain-Dupré, 2018[57]). This is reflected within the recommendations of the economic surveys, which have explicitly identified policy alignment and co-ordination as areas for improvement in several cases (Box 5).

\section{Box 5. Unabsorbed EU funds: An indicator of co-ordination failures and lack of capacity}

Among EU countries, trouble absorbing EU funds can be a sign of poorly co-ordinated fiscal policy as well as inadequate SCG capacity (Figure 7). Recent OECD work has identified both capacity constraints and co-ordination deficiencies as encumbering the use of diverse financing mechanisms by SCGs $\left(\mathrm{OECD}, 2018_{[71]}\right)$. In particular, $68 \%$ of respondents to a 2016 Committee of the Regions survey on obstacles to local and regional investment identified "capacity to design and manage public investment and PPPs funded by the EU Structural Funds and other EU programmes " as either a challenge or major challenge for 
local/regional authorities (OECD-CoR, 2016 $\left.6_{[72]}\right)$. The 2018 OECD economic survey of the European Union highlighted the importance of streamlined administration and enhanced administrative capacity to ensure the uptake of EU funds (OECD, 2018 $\left.8_{[73]}\right)$, particularly when it comes to co-ordinating with SCGs. Country surveys have echoed a similar message. For example, in Italy the central government's failure to work effectively with local administrative agencies was cited as an impediment to the disbursement of EU Structural and Cohesion Funds (OECD, 2017[74]). The survey called for the central government to strengthen its role in setting minimum standards for project preparation and execution, while ensuring that a central co-ordinating agency had sufficient power to support regional efforts in implementing the projects (OECD, 2017 $\left.7_{[74]} ; 2019_{[75]}\right)$. Likewise, the Czech Republic's struggle to effectively absorb EU funds was linked to co-ordination issues arising from a heavily decentralised administration of the associated programmes. In response, a general simplification of the administrative process was recommended (OECD, 2008 $[76]$ ). Beyond EU funds, similar problems can arise when countries are faced with managing their own fiscal space. In Switzerland, surveys called on federal and cantonal governments to improve co-ordination to ensure that the significant fiscal space available was adequately utilised and to avoid persistent underspending (OECD, 2017[77]).

Figure 7. Unabsorbed EU structural and cohesion funds and spending of planned investment

a) Spending of planned investment, 2014-2017

2014-20 programming period, as of end 2017, per cent

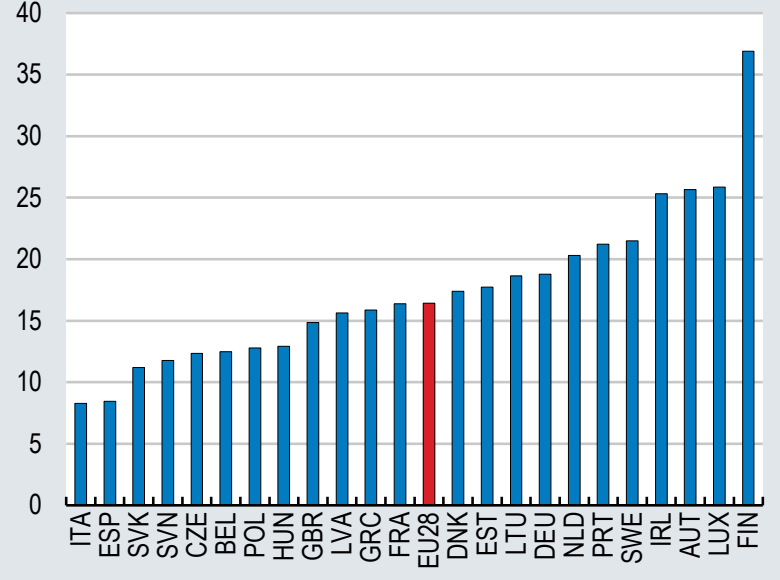

b) Unabsorbed structural and cohesion funds, 2007-2013 2007-13 programming period, as of end 2013, per cent

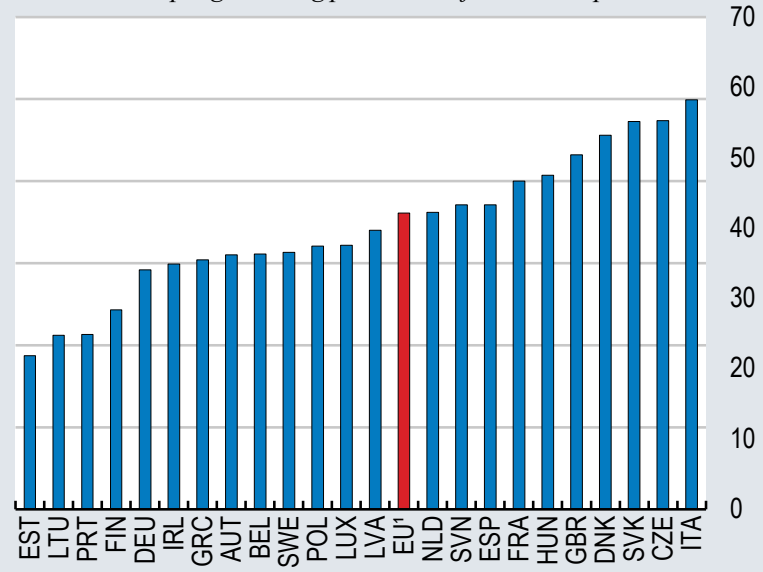

Note: 1. Unweighted average across 25 EU countries.

Source: Caldera Sánchez (2018[78]), data from European Commission (2018), "Open Data Portal for the European Structural and Investment Funds (https://cohesiondata.ec.europa.eu/)"; European Commission (2014), "Analysis of the Budgetary Implementation of the Structural and Cohesion Funds".

StatLink http://dx.doi.org/10.1787/888934116129

64. The economic surveys have recommended increased multi-level co-ordination and policy alignment across a diverse range of government functions. Concerning environmental policy, Spain was urged to improve the horizontal alignment of regional pollution taxes by implementing a uniform tax among jurisdictions to increase efficiency (OECD, 2014 [63]). Austria was urged to focus on the vertical alignment of state and federal environmental objectives. A particular example is a major infrastructure project, which was supported by 
the federal government because it would aid the sustainability of transport, but simultaneously opposed by local government owing to concerns about local nature protection (OECD, 2005 $\left.5_{[44]}\right)$.

65. Other areas where increased co-ordination has been called for include health care, $\mathrm{R} \& \mathrm{D}$, labour market and migration policy. In Australia, improved state-federal coordination in health care was seen as a way of reducing the incentive to cost-shift between levels of government (OECD, 2014[59]). Likewise, it was observed that lack of co-ordination was the leading cause of inefficiency in Switzerland's highly fragmented health care system (OECD, $\left.2015_{[56]}\right)$. In Austria, vertical misalignment between federal and state R\&D support programmes suggested a need for better co-ordination. State administered programmes were designed based solely on the needs of the state, without considering the federal government's broader objective of fostering innovation $\left(\right.$ OECD, 2005 $\left.{ }_{[44]}\right)$. Similarly, Spain was called upon to improve the effectiveness of public investment in $R \& D$ and to reduce duplication through improved co-ordination across levels of government, perhaps via the creation of a national public investment agency $\left(\mathrm{OECD}, 2014_{[63]}\right)$. The same survey noted a vertical misalignment between regions and central government with respect to labour market policy: while central government paid unemployment benefits, it was left to the regions to support job seekers in finding work. In Belgium, migration policy was subject to a complex division of responsibility between the federal government and regions. The federal government oversaw residence permits, while the regions were responsible for certain work permits. A third category of permit, work permits issued to those with limited right of residence (e.g. asylum seekers), was issued by federal authorities. The economic survey therefore called for careful coordination between levels of government, in particular to avoid harmful interregional competition such that variation in work permit rules did not become a distortionary factor in, for example, company location decisions (OECD, 2015 $\left.5_{[43]}\right)$.

66. An important area in which coordination was also advocated for is public investment - and infrastructure more broadly. In 2014, the OECD adopted the Council Recommendation on Effective Public Investment across Levels of Government which promotes vertical and horizontal coordination mechanisms, to enhance the effectiveness of public investment spending $\left(\mathrm{OECD}, 2014_{[79]}\right)$. Specific modes of co-ordination cited include contracts, platforms for dialogue and co-operation, specific public investment partnerships, joint authorities, or regional or municipal mergers.

\subsubsection{Eliminate internal market barriers and regulatory fragmentation}

67. Internal market barriers include any impediment to the free-flow of goods and factors of production within a country that does not serve a useful social purpose. In some cases, such impediments come in the form of inconsistent or fragmented regulatory regimes. Examples include differing professional certification schemes across SCGs, different business licensing procedures, or needless inconsistencies in land-use regulations and building codes.

68. Economic surveys have identified internal market barriers and regulatory fragmentation as challenges in both federal and unitary contexts. However, given the often greater autonomy of SCGs within federations (Phillips, 2018 $8_{[80]}$ ), it is unsurprising that the majority of references to internal market barriers pertain to federal countries. In Germany and Canada, harmonising the recognition of immigrants' qualifications across SCGs was recommended to facilitate integration (OECD, 2016 ${ }_{[32]}$; 2014 $\left.{ }_{[81]}\right)$. In Switzerland, a similar call was made for labour market uniformity by reducing restrictions on labour market access between cantons. Additionally, surveys of Switzerland noted that cantons should harmonise 
building laws and codes (OECD, 2015 $\left.[56] ; 2017_{[77]}\right)$. In Spain, implementing the market unity law was endorsed as a way of reducing the regional barriers to entry posed by fragmentation in the business licensing system (OECD, 2014 $\left.{ }_{[63]}\right)$. Finally, market barriers also present themselves in emerging areas like renewable energy. In Belgium, it was suggested that green and combined heat and power (CHP) certificates be made transferable between all regions (OECD, 2009 $\left.{ }_{[50]}\right)$.

\subsubsection{Benchmark performance nationally and internationally}

69. Monitoring, evaluation and oversight are inseparable from benchmarking. Benchmarking, the comparing of performance measurements to a reference point, has a special significance in the context of fiscal decentralisation. This is because decentralisation implies that benchmarking should take place at both the cross-jurisdictional and crosscountry levels. Phillips $\left(2018_{[80]}\right)$ provides a survey of benchmarking systems, with a focus on the special relevance of benchmarking in decentralised settings as well as approaches to competitive benchmarking.

70. While benchmarking may be applied across all areas of sub-central jurisdiction, economic surveys provide some illustrative examples of contexts where it was explicitly recommended:

- Australia: Benchmarking the management of environmentally sensitive areas (OECD, 2004 $[82])$

- India: Participating in an international survey as a way of benchmarking state-level educational outcomes $\left(\mathrm{OECD}, 2011_{[83]}\right)$. Continuing to benchmark states with respect to one another and to share best practises in "labour regulations and land laws" (OECD, 2016[84]).

- Italy: Using cost benchmarking in public procurement (OECD, 2015 [85]).

- Spain: Benchmarking regional public services with respect to cost and quality (OECD, 2010[86]).

\subsubsection{Improve quality and accessibility of performance data}

71. Benchmarking and performance measurement are dependent on the availability of relevant data at the sub-central level. Yet making quality data accessible is easier said than done. This lead to explicit calls for improving available data on SCG performance in the surveys of Australia (public service quality), France (public service quality and cost), Germany (performance of public-private partnerships), Italy (procurement costs), Mexico (budget disclosure and fiscal transfers) and Switzerland (public salaries).

\subsubsection{Implementing joint procedures and centralising procurement across SCGS}

72. Co-ordination can aid SCGs in overcoming the loss of scale that may be associated with some aspects of decentralisation. For example, a central purchasing body can help achieve larger procurement volumes and/or increased administrative efficiency (OECD, $\left.2015_{[87]}\right)$. These factors have helped to motivate inter-municipal shared service models for procurement in e.g. England (Murray, Rentell and Geere, 2008 ${ }_{[88]}$ ) and Queensland, Australia. In Queensland, the implementation of the Local Buy shared procurement programme was estimated to be saving local authorities between $\$ 4$ million and $\$ 7$ million per year (Dollery, Hallam and Wallis, 2008 ${ }_{[89]}$ ). 
73. Centralising procurement at the sub-national level is a theme observed across several economic surveys. In France, the exceptionally large number of municipalities (communes) was linked to sub-optimal purchasing practises. Centralised, electronic procurement was recommended to standardise processes (OECD, 2015[61]). Similar recommendations were made to Germany, with a particular focus on the need for up-skilling the local civil service (OECD, 2016 $\left.{ }_{[32]}\right)$. In Italy, the survey noted that a massive reduction in the number of sub-national purchasing centres (from 32000 to less than 40) had already been proposed as a way of centralising procurement (OECD, 2015 $[85])$. Finally, Switzerland was encouraged to harmonise procurement rules across cantons to increase process accountability and competition among suppliers (OECD, 2007[90]).

\subsubsection{Build SCG professional capacity}

74. The existence of capacity limitations particular to SCGs is supported by ample evidence. Such capacity limitations can extend to human resources and physical capital within the public sector, including low technical skills of tax officials and limited use of modern IT systems (Ter-Minassian, $2020_{[91]}$ ). This is echoed by survey recommendations calling for professionalisation or up-skilling of the sub-central public service. In both France and Germany, surveys called for improving the skills of employees involved in sub-national procurement $\left(\mathrm{OECD}, 2015_{[61]} ; 2016_{[32]}\right)$. In the German case, this was explicitly linked to the advent of e-procurement, which would require stronger skills in the areas of data analysis and re-use (OECD, 2016 $\left.{ }_{[32]}\right)$.

75. Some middle-income countries have received more general encouragement to increase the technical competency of SCGs. Mexico was urged to build capacity and professionalise the civil service at the state and municipal levels (OECD, 2019[65]). Similarly, Indonesia was advised to expand assistance to help regions to improve budget planning and implementation capacity (OECD, 2016 $\left.6_{[92]}\right)$.

\subsubsection{Enhance monitoring, including through oversight at the national level}

76. Dougherty, Renda and von Trapp $\left(2020_{[4]}\right)$ note the emergence of sub-national independent oversight bodies as a recent extension of the global trend towards using such institutions to support policy development and decision-making. Independent oversight bodies can be divided into three types: Independent Fiscal Commissions (IFIs), Independent Productivity Commissions (IPCs) and Regulatory Oversight Bodies (ROBs).

77. The first and third type, IFIs and ROBs, are of particular interest in the context of fiscal decentralisation because of their respective roles in fiscal scrutiny and policy coordination. Several of the surveys called for the use of oversight bodies or enhanced monitoring to support fiscal decentralisation, typically in a form resembling IFIs or ROBs. Importantly, many of these bodies were proposed at the national level in order to facilitate co-ordination among SCGs. For example, in Belgium it was recommended that the National Account Institute or Federal Planning Bureau expand their scope to examine the fiscal consequences of the then current assignment of responsibilities across levels of government (OECD, 2011 $[67]$ ). Indeed, following the 2013 co-operation agreement on fiscal policy, the High Council on Finance had its scope broadened to monitor compliance with the agreement. The Council explicitly takes into account burden sharing among levels of government to ensure fairness when setting multi-annual budget targets (OECD, 2015 $\left.5_{[43]}\right)$. Similarly, Denmark's central government was encouraged to carefully monitor its division of fiscal responsibilities with local government $\left(\right.$ OECD, 2014 $\left.{ }_{[39]}\right)$. In Mexico, INEE, the national education oversight body, and the Ministry of Education were encouraged to work together 
to enhance the monitoring and evaluation capacity of SCGs (OECD, 2019 $9_{[65]}$ ). In Switzerland, education was also urged to be subject to greater cross-cantonal scrutiny, owing to differences in policy, spending and resources across cantons. In this context, the Swiss Conference of Cantonal Ministers of Education was referenced as an important forum for agreeing on minimum standards (OECD, 2009 $\left.{ }_{[93]}\right)$.

78. Finally, Dougherty et al. $\left(2020_{[4]}\right)$ also identify important instances of oversight bodies at the sub-central level (e.g. Ontario's Financial Accountability Office), noting as well that they may be co-ordinated at the national level (e.g. COAG in Australia). Surveys have sometimes made similar recommendations for oversight at the sub-central level. In Spain, monitoring and evaluation of employment services at the regional level was seen as a second-best alternative to fully assigning the provision of such services to central government (OECD, 2010[86] $)$. 


\section{References}

Akai, N. and M. Sakata (2002), "Fiscal decentralization contributes to economic growth: evidence from state-level cross-section data for the United States", Journal of Urban Economics, Vol. 52/1, pp. 93-108.

Allain-Dupré, D. (2018), “Assigning Responsibilities across Levels of Government”, OECD Working Papers on Fiscal Federalism, No. 24.

Almy, R. (2014), "Valuation and Assessment of Immoveable Property", OECD Working Papers on Fiscal Federalism, No. 19.

Bartolini, D., S. Stossberg and H. Blöchliger (2016), "Fiscal Decentralisation and Regional Disparities", OECD Economics Department Working Papers, No. 1330.

Blöchliger, H. and O. Akgun (2018), "Fiscal decentralisation and economic growth", in Fiscal Decentralisation and Inclusive Growth, OECD Publishing, Paris, https://dx.doi.org/10.1787/9789264302488-4-en.

Blöchliger, H., D. Bartolini and S. Stossberg (2016), "Does Fiscal Decentralisation Foster Regional Convergence?", OECD Economic Policy Papers, No. 17.

Blöchliger, H., B. Égert and K. Fredriksen (2013), "Fiscal Federalism and its Impact on Economic Activity, Public Investment and the Performance of Educational Systems", OECD Economics Department Working Papers, No. 1051.

Boadway, R. and S. Dougherty (2019), "Decentralisation in a globalised world: Consequences and opportunities", in Fiscal Decentralisation and Inclusive Growth in Asia, OECD Publishing, Paris, https://dx.doi.org/10.1787/a47d130f-en.

Brandt, N. (2015), Vocational Training and Adult Learning for Better Skills in France.

Bruxelles environnement (2019), Coordination de la mise en cuvre de la politique de l'eau au niveau belge.

Caldera Sánchez, A. (2018), "Building a stronger and more integrated Europe", $O E C D$ Economics Department Working Papers, No. 1491, OECD Publishing, Paris, https://dx.doi.org/10.1787/4ce667b4-en.

Cournède, B., J. Fournier and P. Hoeller (2018), Public finance structure and inclusive growth, OECD Publishing.

Daude, C., H. Gutiérrez and Á. Melguizo (2013), "What drives tax morale?”, OECD Development Centre Working Papers, No. 315. 
de Mello, L. (2019), Intergovernmental Cooperation: Challenges, Trends and International Experience, Paper prepared for the "Jornada sobre Experiencias de Cooperación y Asistencia entre Municipios", University of Barcelona, Barcelona.

de Mello, L. (2004), “Can Fiscal Decentralisation Strengthen Social Capital?", Public Finance [26] Review, Vol. 32/1, pp. 4-35.

de Mello, L. (2000), "Fiscal Decentralization and Intergovernmental Fiscal Relations", World Development, Vol. 28, pp. 365-380.

Dollery, B., G. Hallam and J. Wallis (2008), "Shared services in Australian local government: A case study of the Queensland local government association model", Economic Papers: A journal of applied economics and policy, Vol. 27/4, pp. 343-354.

Dougherty, S. and O. Akgun (2018), "Globalisation, decentralisation and inclusive growth", in Fiscal Decentralisation and Inclusive Growth, OECD Publishing, Paris, https://dx.doi.org/10.1787/9789264302488-5-en.

Dougherty, S., M. Harding and A. Reschovsky (2019), "Twenty years of tax autonomy across levels of government: measurement and applications", OECD Working Papers on Fiscal Federalism, No. 29, forthcoming.

Dougherty, S. et al. (2019), "The impact of decentralisation on the performance of health care systems: A non-linear relationship", OECD Fiscal Federalism Working Papers, No. 27.

Dougherty, S. and L. Phillips (2019), "The spending power of sub-national decision makers across five policy sectors", OECD Working Papers on Fiscal Federalism, No. 25, OECD Publishing, Paris, https://dx.doi.org/10.1787/8955021f-en.

Dougherty, S., A. Renda and L. Trapp (2020), "Independent oversight bodies: lessons from fiscal, productivity and regulatory institutions", in Institutions and Institutionalisation, HRSC Press.

Filippetti, A. and A. Sacchi (2016), "Decentralization and economic growth reconsidered: The role of regional authority", Environment and Planning C: Government and Policy, Vol. 34/8, pp. 1793-1824.

Gemmell, N., R. Kneller and I. Sanz (2013), "Fiscal decentralization and economic growth: spending versus revenue decentralization”, Economic Inquiry, Vol. 51/4, pp. 1915-1931.

Hagemann, R. (2018), “Tax Policies for Inclusive Growth: Prescription versus Practice", OECD Economic Policy Papers, No. 24.

Kim, J. (2018), "Fiscal decentralisation and inclusive growth: An overview", in Fiscal Decentralisation and Inclusive Growth, OECD Publishing, Paris, https://dx.doi.org/10.1787/9789264302488-3-en.

Lastra-Anadón, C. and S. Mukherjee (2019), "Cross-country evidence on the impact of decentralisation and school autonomy on educational performance", OECD Working Papers on Fiscal Federalism, No. 26. 
Martinez-Vazquez, J., S. Lago-Peñas and A. Sacchi (2017), "The Impact of Fiscal Decentralization: A Survey”, Journal of Economic Surveys, Vol. 31/4, pp. 1095-1129.

Murray, J., P. Rentell and D. Geere (2008), "Procurement as a shared service in English local government", International Journal of Public Sector Management, Vol. 21/5, pp. 540-555.

Oates, W. (1972), Fiscal Federalism, Edward Elgar Publishing.

Oates, W. and R. Schwab (1988), "Economic competition among jurisdictions: efficiency enhancing or distortion inducing?", Journal of Public Economics, Vol. 35/3, pp. 333-354.

OECD (2019), Making Decentralisation Work: A Handbook for policymakers, OECD Publishing.

OECD (2019), OECD Economic Surveys: Italy 2019, OECD Publishing.

OECD (2019), OECD Economic Surveys: Mexico 2019, OECD Publishing.

OECD (2018), Monitoring Report: Implementation of the Recommendation of the Council on Effective Public Investment across Levels of Government, OECD Publishing.

OECD (2018), OECD Economic Surveys: European Union 2018, OECD Publishing, Paris, https://dx.doi.org/10.1787/eco_surveys-eur-2018-en.

OECD (2018), OECD Economic Surveys: Germany 2018, OECD Publishing, Paris.

OECD (2017), OECD Economic Surveys: Italy 2017, OECD Publishing.

OECD (2017), OECD Economic Surveys: Japan 2017, OECD Publishing.

OECD (2017), OECD Economic Surveys: Switzerland 2017, OECD Publishing.

OECD (2016), Fiscal Federalism 2016: Making decentralisation work, OECD Publishing.

OECD (2016), OECD Economic Surveys: Germany 2016, OECD Publishing.

OECD (2016), OECD Economic Surveys: India 2016, OECD Publishing.

OECD (2016), OECD Economic Surveys: Indonesia 2016, OECD Publishing.

OECD (2016), OECD Economic Surveys: Norway 2016, OECD Publishing, Paris, https://dx.doi.org/10.1787/eco surveys-nor-2016-en.

OECD (2015), Government at a Glance 2015, OECD Publishing.

OECD (2015), OECD Economic Surveys: Belgium 2015, OECD Publishing, Paris, https://dx.doi.org/10.1787/eco_surveys-bel-2015-en.

OECD (2015), OECD Economic Surveys: France 2015, OECD Publishing. 
OECD (2015), OECD Economic Surveys: Italy 2015, OECD Publishing.

OECD (2015), OECD Economic Surveys: Switzerland 2015, OECD Publishing.

OECD (2014), OECD Economic Surveys: Australia 2014, OECD Publishing.

OECD (2014), OECD Economic Surveys: Canada 2014, OECD Publishing.

OECD (2014), OECD Economic Surveys: Denmark 2014, OECD Publishing.

OECD (2014), OECD Economic Surveys: Finland 2014, OECD Publishing.

OECD (2014), OECD Economic Surveys: Spain, OECD Publishing.

OECD (2014), Recommendation of the Council on Effective Public Investment Across Levels of Government, OECD Publishing.

OECD (2013), "Fiscal equalisation: A key to decentralised public finances", in Fiscal Federalism 2014: Making Decentralisation Work, OECD Publishing, Paris, https://dx.doi.org/10.1787/9789264204577-7-en.

OECD (2013), Fiscal Federalism 2014: Making Decentralisation Work, OECD Publishing, Paris, https://dx.doi.org/10.1787/9789264204577-en.

OECD (2013), OECD Economic Surveys: Mexico 2013, OECD Publishing.

OECD (2012), “Denmark: The Local Government Reform”, in Reforming Fiscal Federalism and Local Government: Beyond the Zero-Sum Game, OECD Publishing, Paris, https://dx.doi.org/10.1787/9789264119970-8-en.

OECD (2012), OECD Economic Surveys: Denmark 2012, OECD Publishing.

OECD (2011), OECD Economic Surveys: India 2011, OECD Publishing.

OECD (2010), OECD Economic Surveys: Norway 2010, OECD Publishing.

OECD (2010), OECD Economic Surveys: Spain 2010, OECD Publishing.

OECD (2010), OECD Economic Surveys: The Netherlands 2010, OECD Publishing.

OECD (2009), OECD Economic Surveys: Belgium 2009, OECD Publishing.

OECD (2009), OECD Economic Surveys: Brazil 2009, OECD Publishing.

OECD (2009), OECD Economic Surveys: Switzerland 2009, OECD Publishing.

OECD (2008), OECD Economic Surveys: Korea 2008, OECD Publishing. 
OECD (2008), OECD Economic Surveys: Spain 2008, OECD Publishing.

OECD (2008), OECD Economic Surveys: The Czech Republic, OECD Publishing.

OECD (2007), OECD Economic Surveys: Italy 2007, OECD Publishing.

OECD (2007), OECD Economic Surveys: Spain 2007, OECD Publishing.

OECD (2007), OECD Economic Surveys: Switzerland 2007, OECD Publishing.

OECD (2006), OECD Economic Surveys: Australia 2006, OECD Publishing.

OECD (2006), OECD Economic Surveys: Germany 2006, OECD Publishing.

OECD (2006), OECD Economic Surveys: Switzerland 2006, OECD Publishing.

OECD (2005), OECD Economic Surveys: Austria 2005, OECD Publishing.

OECD (2005), OECD Economic Surveys: Japan 2005, OECD Publishing.

OECD (2005), OECD Economic Surveys: Korea 2005, OECD Publishing.

OECD (2005), OECD Economic Surveys: United States 2005, OECD Publishing.

OECD (2004), OECD Economic Surveys: Australia 2004, OECD Publishing.

OECD/KIPF (2016), Fiscal Federalism 2016: Making Decentralisation Work, OECD Publishing, Paris, https://dx.doi.org/10.1787/9789264254053-en.

OECD-CoR (2016), Results of the survey on regional and local obstacles to investments, Committee of the Regions, European Commission.

Phillips, L. (2018), "Improving the Performance of Sub-national Governments through Benchmarking and Performance Reporting", OECD Working Papers on Fiscal Federalism, No. 22, OECD Publishing, Paris, https://dx.doi.org/10.1787/ffff92c6-en.

Qiao, B., J. Martinez-Vazquez and Y. Xu (2008), "The tradeoff between growth and equity in decentralization policy: China's experience", Journal of Development Economics, Vol. 86/1, pp. 112-128.

Sow, M. and I. Razafimahefa (2018), "Fiscal decentralisation and the efficiency of public service delivery", in Fiscal Decentralisation and Inclusive Growth, OECD Publishing, Paris, https://dx.doi.org/10.1787/9789264302488-11-en.

Stossberg, S. and H. Blöchliger (2017), "Fiscal Decentralisation and Income Inequality: Empirical Evidence from OECD Countries", Journal of Economics and Statistics (Jahrbuecher fuer Nationaloekonomie und Statistik), Vol. 237/3, pp. 225-273.

Ter-Minassian, T. (2020), “Challenges of subnational capacity development”, OECD Fiscal Federalism Working Papers, forthcoming. 
Ter-Minassian, T. and L. de Mello (2016), "Intergovernmental Fiscal Cooperation”, Interamerican Development Bank Technical Notes, No. IDB-TN-1048.

Tiebout, C. (1956), "A pure theory of local expenditures.", The Journal of Political Economy, Vol. 64, pp. 416-424.

Xie, D., H. Zou and H. Davoodi (1999), "Fiscal Decentralization and Economic Growth in the United States", Journal of Urban Economics, Vol. 45/2, pp. 228-239.

Zhang, T. and H. Zou (1998), "Fiscal decentralization, public spending, and economic growth [17] in China", Journal of Public Economics, Vol. 67/2, pp. 221-240. 